\title{
Expressing Cloned Genes for Protein Production, Purification, and Analysis
}

\author{
Clara L. Kielkopf, William Bauer, and Ina L. Urbatsch
}

\begin{abstract}
Obtaining high quantities of a specific protein directly from native sources is often challenging, particularly when dealing with human proteins. To overcome this obstacle, many researchers take advantage of heterologous expression systems by cloning genes into artificial vectors designed to operate within easily cultured cells, such as Escherichia coli, Pichia pastoris (yeast), and several varieties of insect and mammalian cells. Heterologous expression systems also allow for easy modification of the protein to optimize expression, mutational analysis of specific sites within the protein and facilitate their purification with engineered affinity tags. Some degree of purification of the target protein is usually required for functional analysis. Purification to near homogeneity is essential for characterization of protein structure by X-ray crystallography or nuclear magnetic resonance (NMR) and characterization of the biochemical and biophysical properties of a protein, because contaminating proteins almost always adversely affect the results. Methods for producing and purifying proteins in several different expression platforms and using a variety of vectors are introduced here.
\end{abstract}

\section{OVERVIEW OF EXPRESSION SYSTEMS}

Escherichia coli is the first choice for expression of many heterologous proteins because of the vast fund of knowledge about its genetics, biochemistry, and molecular biology. Genetic manipulations are straightforward, cultures of $E$. coli are easily and inexpensively grown, and many foreign proteins are well tolerated and may be expressed at high levels. During the past 30 years, more than 30,000 recombinant proteins have been successfully expressed and purified using E. coli (Graslund et al. 2008). However, E. coli is not always the host of choice. For example, proteins whose full biological activity requires posttranslational modification (e.g., glycosylation or cleavage at specific sites) may best be expressed in a eukaryotic host, such as the yeast Pichia pastoris or the baculovirus-infected insect cell systems that have emerged since the late 1980s. Before embarking on an expression project, it is important to assess the final goal and to determine which host-vector system is most likely to be most appropriate for expressing the target protein.

Expression of proteins in E. coli is a relatively straightforward, cost-effective means for producing large quantities of simple proteins that do not require posttranslational modification. Eukaryotic proteins expressed in insect cells using baculovirus systems are likely to achieve important processing or modifications required for proper function. The baculovirus system is relatively approachable given many commercial options available to assist the user. Advantages of the P. pastoris expression system, in addition to eukaryotic processing, include the ease of generating expression vectors, the opportunity to coexpress partner proteins, and high biomass production. This system facilitates production of large quantities of native protein, enabling biochemical, physiological, or structural studies (Daly and Hearn

From the Molecular Cloning collection, edited by Michael R. Green and Joseph Sambrook.

(C) 2021 Cold Spring Harbor Laboratory Press

Cite this introduction as Cold Spring Harb Protoc; doi:10.1101/pdb.top102129 
C.L. Kielkopf et al.

2005). As such, the Pichia system represents a cost-effective, versatile alternative in the protein expression "toolbox" (Cregg et al. 2000). Protocol: Expression of Cloned Genes in E. coli Using IPTG-Inducible Promoters (Kielkopf et al. 2021a), Protocol: Subcellular Localization of Signal Peptide Fusion Proteins Expressed in E. coli (Kielkopf et al. 2021b), Protocol: Expression of Cloned Genes Using the Baculovirus Expression System (Kielkopf et al. 2020a), and Protocol: Expression of Cloned Genes in Pichia pastoris Using the Methanol-Inducible Promoter AOX1 (Kielkopf et al. 2021c) describe the methods for expression of proteins in E. coli, insect, or Pichia cells.

Fusions of the protein of interest with a carrier protein can increase solubility, change the localization, provide a means for affinity purification, or elicit a response in immunological assays. A variety of cleavable fusion tags may facilitate purification and detection. Procedures for cell lysis and purification of the common polyhistidine (6xHis) or glutathione $S$-transferase (GST)-fusion proteins are given in Protocol: Preparation of Cell Extracts for Purification of Soluble Proteins Expressed in E. coli (Kielkopf et al. 2021d), Protocol: Purification of Polyhistidine-Tagged Proteins by Immobilized Metal Affinity Chromatography (Kielkopf et al. 2020b), and Protocol: Purification of Fusion Proteins by Affinity Chromatography on Glutathione Resin (Kielkopf et al. 2020c). In some cases, proteins expressed in E. coli are found in insoluble inclusion bodies. Although baculovirus or Pichia expression systems (Protocol: Preparation of Cell Extracts for Purification of Proteins Expressed in Pichia pastoris [Kielkopf et al. 2021e]) provide viable alternatives for production of soluble, active protein, Protocol: Solubilization of Expressed Proteins from Inclusion Bodies (Kielkopf et al. 2021f) describes a procedure for isolating and recovering protein from inclusion bodies expressed in E. coli. Fundamental techniques for analyzing the quantity and purity of expressed proteins include SDSpolyacrylamide gel electrophoresis, immunoblotting (or western blots), and using the Bradford assay or $A_{280}$ absorbance to determine protein concentration.

\section{CHOOSING AN EXPRESSION SYSTEM}

The attributes and drawbacks of several systems for recombinant protein expression are summarized in Table 1 and described below. Chief considerations when choosing an expression system include the size of the protein, the amount of protein required, the species from which the protein is derived, and any disulfide bonds or posttranslational modifications of the protein. If only small quantities of the target protein are needed-for example, when screening a series of site-directed mutants for enzymatic activity-there is little point in trying to optimize production. However, if purification of an active protein is necessary and/or if the protein is required in large quantities, it may be necessary to explore several different host-vector systems, expression conditions, and/or purification schemes before finding one that is workable on a large scale (Fig. 1).

E. coli

The E. coli system is usually the first choice for expression of small cytosolic proteins or domains. Protein production in E. coli is highly cost effective and convenient, given the simple media requirements and conditions for culture. Moreover, the speed of the E. coli system is exceeded only by cellfree expression (a few hours to produce protein), because the doubling times of E. coli ( $\sim 20 \mathrm{~min}$ ) are rapid compared with those of yeast $(\sim 2 \mathrm{~h})$, insect, or mammalian cells $(\sim 20 \mathrm{~h})$. In general, expression of recombinant proteins in E. coli involves (1) introducing a plasmid that encodes the desired protein into an expression host strain, (2) growing cells to exponential phase, and (3) inducing protein expression. Over the years, a wide array of E. coli strains, expression protocols, and vectors capable of producing very high levels of protein ( $>50 \%$ of total cell protein) have been developed (as described in Protocol: Expression of Cloned Genes in E. coli Using IPTG-Inducible Promoters [Kielkopf et al. 2021a] and Protocol: Subcellular Localization of Signal Peptide Fusion Proteins Expressed in E. coli [Kielkopf et al. 2021b]). However, for a variety of reasons, not all proteins can be successfully expressed in soluble, active form using the E. coli system. Some proteins may be toxic to E. coli 

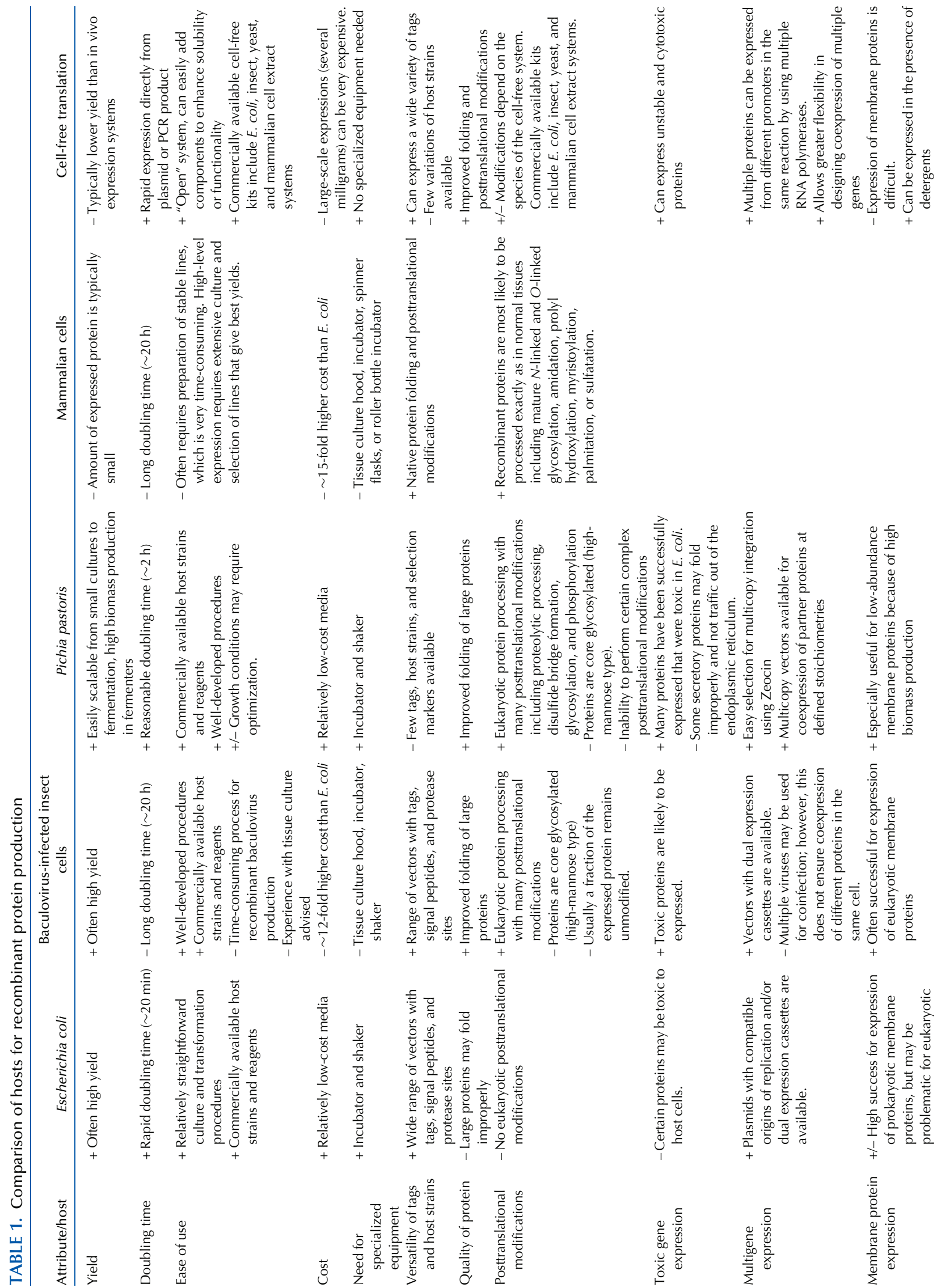

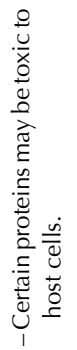
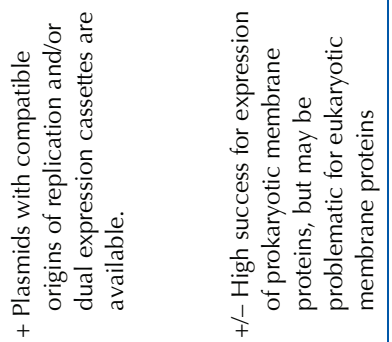
C.L. Kielkopf et al.

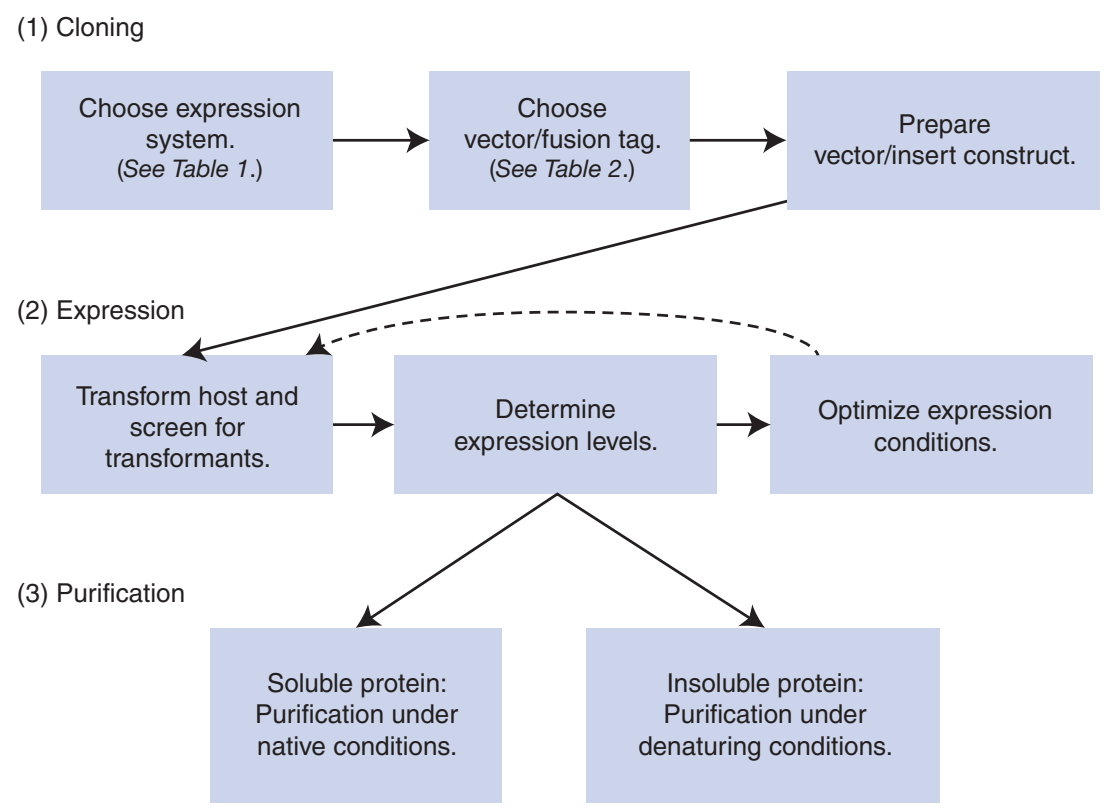

FIGURE 1. Overall strategy for recombinant protein expression and purification.

when overexpressed (Saida 2007). Large proteins often aggregate; the fraction of proteins found in the soluble fraction of $E$. coli cell lysate decreases inversely with protein size ( $>100$ residues) (Graslund et al. 2008). Furthermore, the E. coli host does not provide posttranslational modifications that may be important for the folding and/or activity of eukaryotic proteins. These large and/or eukaryotic proteins often collect in insoluble aggregates called "inclusion bodies" (Marston 1986). Although the recombinant protein may be purified from the inclusion bodies as described in Protocol: Solubilization of Expressed Proteins from Inclusion Bodies (Kielkopf et al. 2021f), the likelihood of refolding to produce soluble, active protein is low (Cabrita and Bottomley 2004; Graslund et al. 2008). Furthermore, the protein typically recovered after refolding is not always compatible with techniques that require large amounts of pure, active, and properly folded protein, such as crystallographic or nuclear magnetic resonance structure analysis. In some cases, altering the E. coli host strains, vectors, and growth conditions may improve protein recovery. In other cases, the alternative expression systems described below should be pursued to increase the chances of producing soluble, active protein.

\section{Baculovirus-Infected Insect Cells}

The general strategy of the baculovirus expression system is to infect insect cells with a virus that expresses a foreign protein at a very late stage of infection. For single-domain or prokaryotic proteins, the E. coli expression system is usually chosen over the baculovirus system because of the higher costs of insect cell media coupled with the time and expertise required to produce recombinant baculovirus. Nevertheless, the baculovirus expression system has several advantages for producing multidomain eukaryotic proteins, including the following.

1. The yields of protein per liter of insect cell culture can rival those produced by a comparable quantity of E. coli cells.

2. Because the protein of interest usually is expressed at a very late phase of virus infection, toxic genes can be expressed with few adverse effects on yield.

3. The relatively low temperature for insect cell growth $\left(27^{\circ} \mathrm{C}-28^{\circ} \mathrm{C}\right)$ can facilitate folding of mutant or unstable proteins.

4. The foreign DNA sequences can be very large ( $>20 \mathrm{~kb}$, corresponding to $>7000$ amino acids) because of the open-ended structure of the virus capsid. 
5. Multiprotein complexes can be produced by simply coinfecting insect cells with more than one recombinant virus as well as by insertion of multiple expression cassettes into the viral genome.

6. Insect cells are capable of splicing introns from pre-mRNA transcripts, although cDNAs are recommended because alternative splicing patterns may cause complications.

7. Insect cells accomplish posttranslational modifications of eukaryotic proteins, with reported modifications, including phosphorylation (Miyamoto et al. 1985), acetylation (Kluwe et al. 1995), carboxymethylation (Rosenberg et al. 1998), prenylation (Khosravi-Far and Der 1995; Lindorfer et al. 1996), signal peptide cleavage (Smith et al. 1985), and proteolytic processing (Oker-Blom et al. 1989). Insect cells also perform $N$ - and $O$-linked glycosylation of foreign proteins (Stiles and Wood 1983; Kuroda et al. 1990). However, the composition and length of the attached glycosyl groups usually do not correspond to those found in mammalian cells (Thomsen et al. 1990; Altmann et al. 1995).

The chief argument for choosing the baculovirus over the E. coli expression systems is the ability of insect cells to accomplish posttranslational modifications of eukaryotic proteins (see point 7 , above). Unfortunately, the overexpressed protein often overwhelms the insect cell machinery so that only a fraction of it is modified (Hoss et al. 1990; Kuroda et al. 1991; Khosravi-Far and Der 1995; Hsu and Betenbaugh 1997). For example, only $10 \%-50 \%$ of ras-related proteins are prenylated when expressed using a baculovirus system (Lowe et al. 1991; Yang et al. 1992; Khosravi-Far and Der 1995). For applications that require homogeneous material, strategies must be developed to identify and separate the processed from the unprocessed forms of the recombinant protein. Alternatively, chaperones or enzymes may be expressed beside the protein of interest to increase processing of recombinant proteins (e.g., Hsu and Betenbaugh 1997; Ailor et al. 1999). This strategy also is used to introduce posttranslational modifications that insect cells lack. For example, the transgenic SfSWT-1 (marketed as the Mimic strain from Life Technologies) insect cell line stably expresses mammalian glycosyl transferases and produces complex sialylated glycoproteins when cultured with a source of sialic acid (such as fetal bovine serum) (Hollister et al. 2002). Despite these solutions, the ability to produce recombinant mammalian proteins with bona fide posttranslational modifications remains a strong rationale for choosing a mammalian over a baculovirus expression system.

\section{Pichia pastoris}

As a system for producing eukaryotic proteins, P. pastoris has many advantages, such as proteolytic processing, protein folding, disulfide-bond formation, and glycosylation, while being as easy to manipulate as E. coli or Saccharomyces cerevisiae (Cereghino and Cregg 1999). It is faster and less expensive than other eukaryotic expression systems and generally gives higher expression levels. Expression vectors are stably integrated into the genome via homologous recombination, in contrast to other expression systems in which the gene resides in episomal plasmids. Transformation is simple (requiring no viral stocks), and expression strains can be stored long term ( $>10 \mathrm{yr}$ ) without loss of viability. The low cost of culture media, the ease of scaling up from small cultures to fermentation cultures, and high biomass production in fermenters (up to $400 \mathrm{~g} / \mathrm{L}$ ) combine to make Pichia a very useful protein expression system. Several thousand heterologous proteins have now been expressed in P. pastoris (Cregg 2007), including many eukaryotic and integral membrane proteins that were nonfunctional when expressed in E. coli (Lueking et al. 2003; Parcej and Eckhardt-Strelau 2003; Long et al. 2005; Andre et al. 2006; Aller et al. 2009); see also Introduction: Considerations for Membrane Protein Purification (Kielkopf et al. 2021g).

Proteins expressed in P. pastoris are usually core glycosylated with short-chain $\mathrm{N}$-glycans of the high-mannose type that may interfere with applications in which immunogenic reactions are undesirable (e.g., immunoglobulin G [IgG] production for medical applications) (Daly and Hearn 2005). Consequently, two groups have genetically engineered $P$. pastoris strains so that they mimic human glycosylation patterns with restricted or fully humanized, terminally sialylated $\mathrm{N}$-glycans (Hamilton et al. 2006; Jacobs et al. 2009). Strains developed by the Contreras group (GlycoSwitch technology) are 
C.L. Kielkopf et al.

available to investigators and can be licensed through Research Corporation Technologies, Inc. Another potential drawback of $P$. pastoris, compared with mammalian systems, is the absence of certain complex posttranslational modifications, such as prolyl hydroxylation, amidation, and some types of phosphorylation, which may be important for proper folding and processing (Cereghino and Cregg 1999). Furthermore, some proteins may be toxic to $P$. pastoris when overexpressed and are consequently retained in the endoplasmic reticulum (ER), misfolded, or degraded by vacuolar and proteasomal degradation machineries (Sullivan et al. 2003; Schuck et al. 2009). Optimization of growth conditions or use of protease-deficient strains may rescue the protein in some cases. In other cases, insect cell or mammalian expression systems may be more suitable alternatives.

\section{Other Expression Systems}

Mammalian cells and cell-free expression systems derived from them are further alternatives to the E. coli, insect cell, and P. pastoris hosts are commonly used for protein expression. As summarized in Table 1, protein expression in mammalian cells offers the advantage of appropriate posttranslational modifications of mammalian proteins. However, drawbacks include (1) the time required for generating the desired amounts of the protein of interest and (2) the relatively high costs. Consequently, the cell-free expression systems have emerged recently as a popular alternative for rapid production of proteins on small or medium scales (up to $3 \mathrm{mg}$ ). As further described in Box 1, Cell-Free Systems for In Vitro Protein Expression, many cell-free expression kits are now commercially available and are well documented by manufacturer's protocols. The protocols cited in this introduction focus on use of the E. coli, insect cell, and $P$. pastoris systems for protein expression.

\section{BOX 1. CELL-FREE SYSTEMS FOR IN VITRO PROTEIN EXPRESSION}

The use of cell-free systems for the in vitro expression of target proteins is becoming increasingly popular and can provide a quick alternative to cell-based in vivo expression (for reviews, see Hoffmann et al. 2004; Murthy et al. 2004; Katzen et al. 2005; Endo and Sawasaki 2006; Falzon et al. 2006). Cell-free systems contain all of the necessary components, such as RNA polymerases, ribosomes, tRNAs, transcription factors, and regulatory proteins, required for protein synthesis. In vitro systems are typically derived from cell lysates but also can be reconstituted from purified components, although protein production is often less efficient in the latter case (Hillebrecht and Chong 2008).

Historically, cell-free protein expression systems were developed to study the mechanisms of protein biosynthesis, particularly the process of protein translation (Nirenberg and Matthaei 1961). In vitro protein synthesis has since evolved to become a tool used for the rapid production of proteins from either an mRNA or DNA template. DNA templates, derived from plasmids or polymerase chain reaction (PCR)-generated templates, typically contain (1) a bacteriophage promoter for transcription of the template DNA by a cognate, bacteriophage-encoded DNA-dependent RNA polymerase and (2) a Shine-Dalgarno sequence to increase the efficiency of translation. Mammalian expression systems usually require an internal ribosome entry site (IRES), Kozak sequence (Kozak 1987), followed by the target sequence, a signal for addition of poly(A), a transcriptional terminator, and a translation enhancer sequence (Hino et al. 2008). Transcription and translation of the target can be performed consecutively (uncoupled) or simultaneously (coupled), depending on the components of the in vitro reactions. Coupled reactions are preferred because they produce a higher yield in less time, but they require additional nucleoside triphosphates (NTPs) and a bacteriophage-encoded DNA-dependent RNA polymerase. The coupled reaction is initiated by combining an extract containing the transcription/translation machinery with the template nucleotide and amino acids. After a short incubation period (typically $30 \mathrm{~min}$ ), the necessary cofactors and energy sources are added to produce the target protein. In uncoupled reactions, transcription and translation are performed in two separate stages, thus providing the opportunity to use mRNA as a starting template.

\section{Advantages}

In vitro cell-free expression can provide several benefits when compared with more traditional $E$. coli expression methods. One of the greatest advantages is being able to quickly produce the protein under 


\section{BOX 1. Continued}

relatively native conditions. Using an expression system that more closely mimics the native expression conditions of the protein can allow for the proper posttranslational modifications and folding of the protein (see, e.g., Gibbs et al. 1985; Hillebrecht and Chong 2008). Working with a cell-free system also allows for the easy addition of components that may enhance protein solubility or functionality. The target protein can be produced at a much faster rate, often within a few hours (as short as $3 \mathrm{~h}$ in E. coli extracts), compared with traditional cell-based methods that are performed overnight for bacterial cultures or over the course of several weeks for proteins expressed in baculovirus vectors. Furthermore, expression of proteins in vitro helps to avoid protein aggregation into inclusion bodies and enables the synthesis of unstable, easily degraded, or cytotoxic proteins that cannot be produced in live cells. In vitro protein synthesis can be performed as a microliter-scale synthesis, which facilitates, for example, expression and screening of mutant forms of the target protein (Yokoyama 2003; Spirin 2004). Conversely, these reactions can be scaled up to express larger quantities of protein. However, large-scale production can often be more technically demanding and prohibitively expensive when compared with cell-based expression. Consequently, in vitro expression may not be a practical option, particularly considering how inexpensive and relatively effortless some in vivo expression methods can be.

\section{Types of In Vitro Expression Systems}

Cells of several species have been used to generate in vitro expression systems: E. coli (Zubay 1973), rabbit reticulocytes (Pelham and Jackson 1976), wheat germ (Roberts and Paterson 1973), insect (Glocker et al. 1993), and human (McDowell et al. 1972; Stueber et al. 1984; Mikami et al. 2008). Each species of cell-free expression system has its own advantages and is capable of adding different posttranslational modifications to the expressed protein (Endo and Sawasaki 2006; Falzon et al. 2006). Mammalian systems are capable of producing more complex modifications but are often expensive, more sensitive to additives, and generate lower yields. Prokaryotic systems, such as E. coli, produce much higher yields and are relatively tolerant of additives, but they cannot create the modifications found on some mammalian proteins nor can they provide environments conducive to correct folding of mammalian proteins.

Such issues create a possible trade-off between the quality and quantity of the protein. For example, cellfree systems from $E$. coli and wheat germ extracts are not able to glycosylate proteins but can produce high yields. Rabbit reticulocyte systems (with canine microsomal membranes added) can produce glycosylated proteins but with a lower overall protein yield. Because all of the posttranslational modifications and proteinfolding differences between the above-mentioned expression systems are not well understood, it may be beneficial to test a few systems to determine which one will produce a functional gene product with the desired posttranslational modifications and yield. Several companies now provide in vitro expression systems derived from several species as kits that include the necessary transcription and translation components: Thermo Scientific Pierce, 1-Step Human Coupled IVT Kits (HeLa cell lysate; https://www.thermofisher. com/us/en/home.html); Life Technologies Invitrogen, Expressway Maxi Cell-Free E. coli Expression System or Ambion Retic Lysate IVT Kit (respectively, E. coli extract or rabbit reticulocyte lysate http://www. thermofisher.com/us/en/home.html); Promega, TNT Systems (wheat germ extract, insect cell lysate, or rabbit reticulocyte lysate; https://www.promega.com/; and QIAGEN, EasyXpress Protein Synthesis Systems (E. coli extract or insect cell lysate; https://www.qiagen.com/us/).

\section{CHOOSING AN APPROPRIATE EXPRESSION VECTOR}

Once a suitable host has been identified, a variety of DNA vectors are available with engineered cloning sites and noncoding sequences to drive protein expression. The promoters are commonly inducible to prevent expression of the target protein until adequate cell growth is achieved. Most vectors also provide the option of creating a fusion protein comprised of target sequences and any one of a number of tag proteins that may increase solubility and simplify subsequent purification (as described in the following section, Fusion Proteins). Common classes of expression vectors are arranged below according to the type of host system used for expression and are summarized in Table 2. 


\section{C.L. Kielkopf et al.}

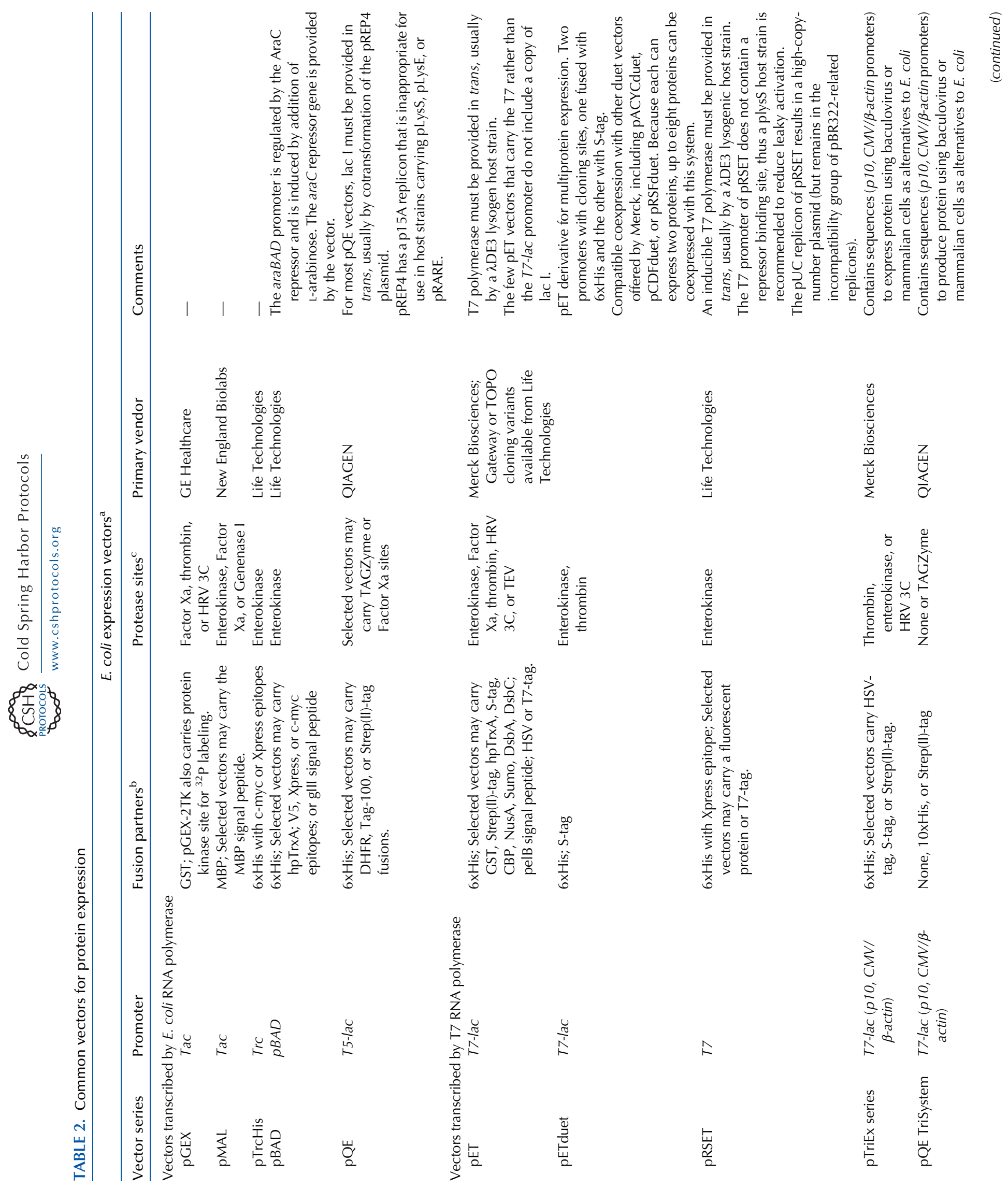


Downloaded from http://cshprotocols.cshlp.org/ on April 26, 2023 - Published by

Expressing Cloned Genes for Protein Production
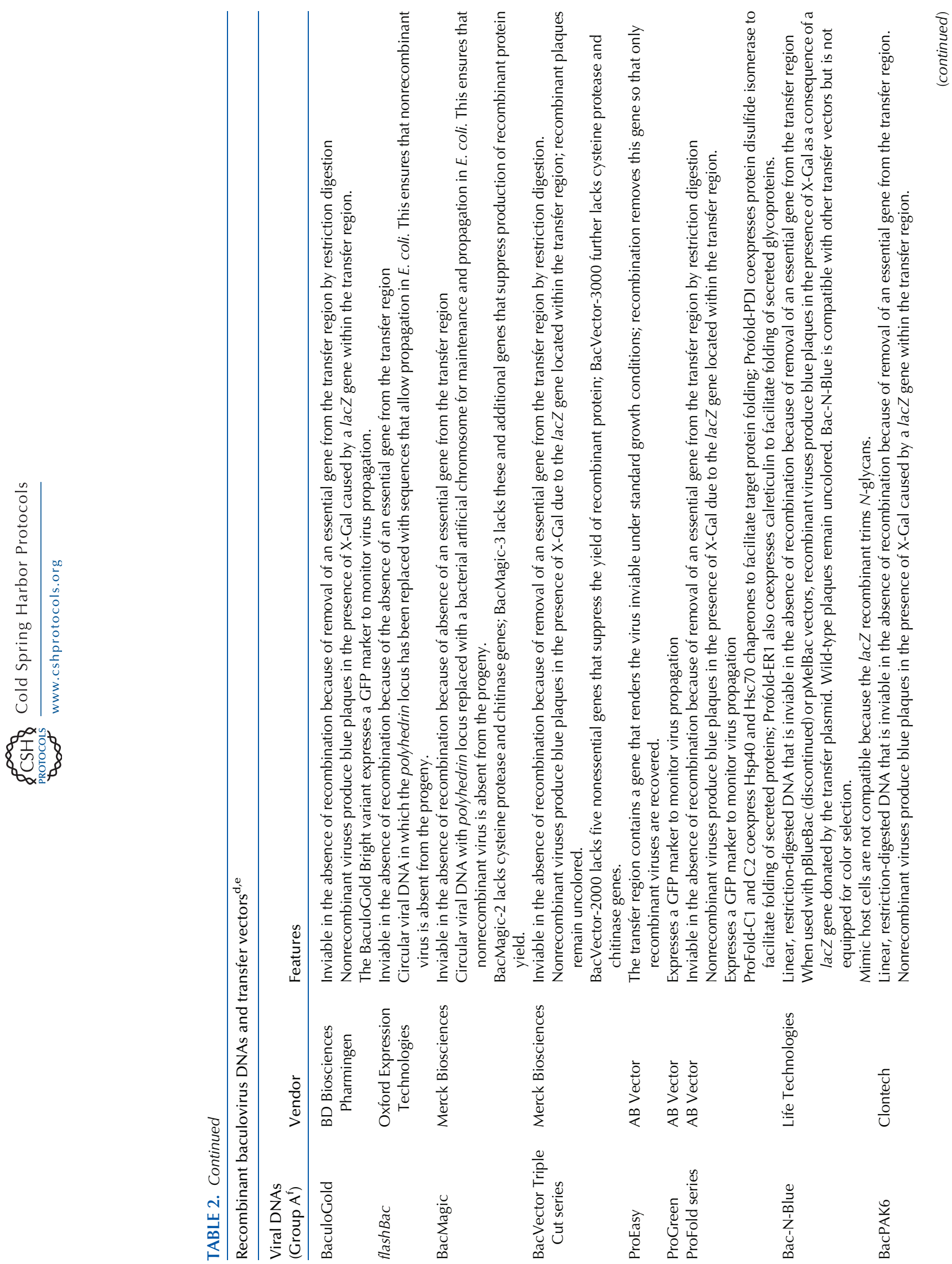


\section{C.L. Kielkopf et al.}

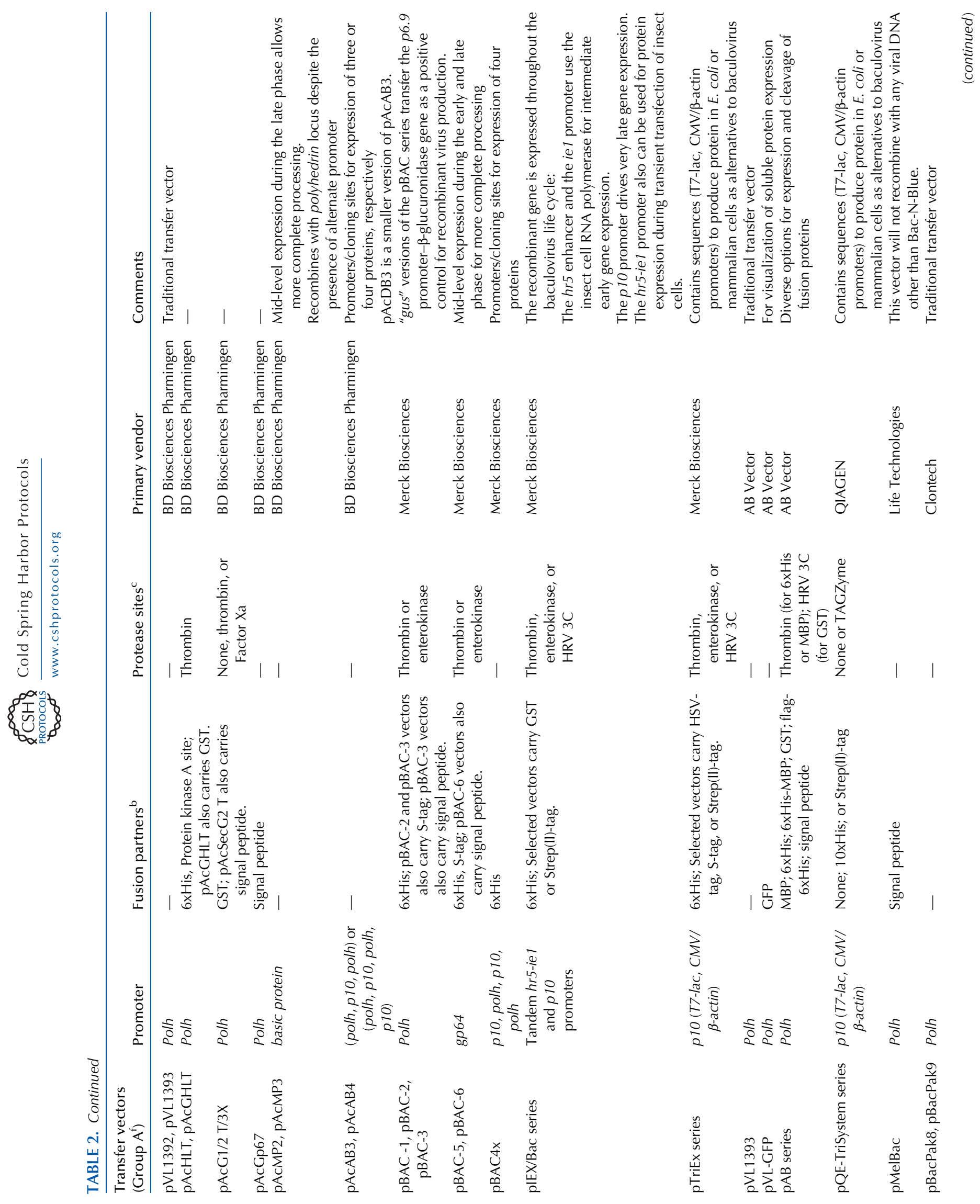


Expressing Cloned Genes for Protein Production

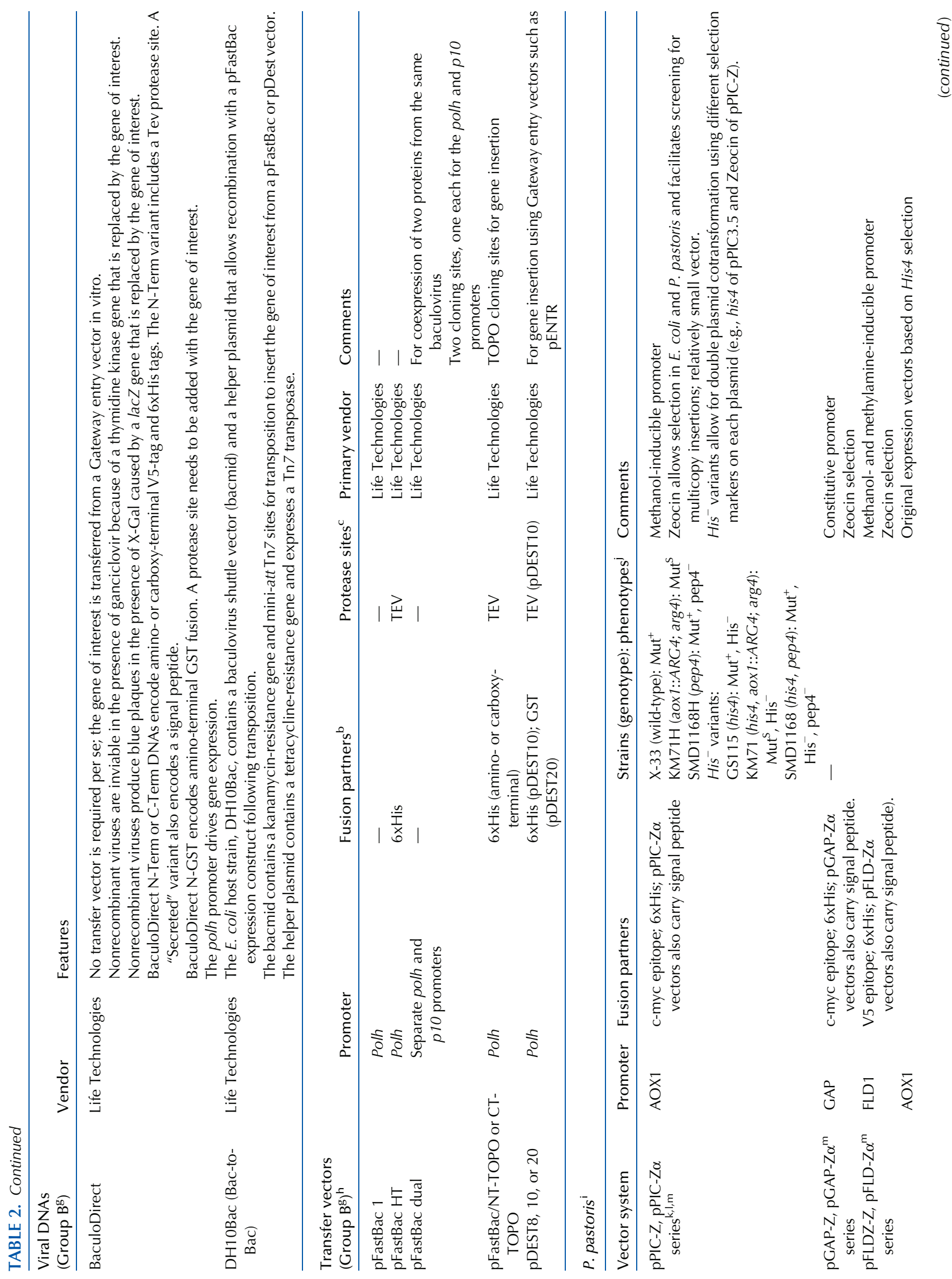




\section{C.L. Kielkopf et al.}
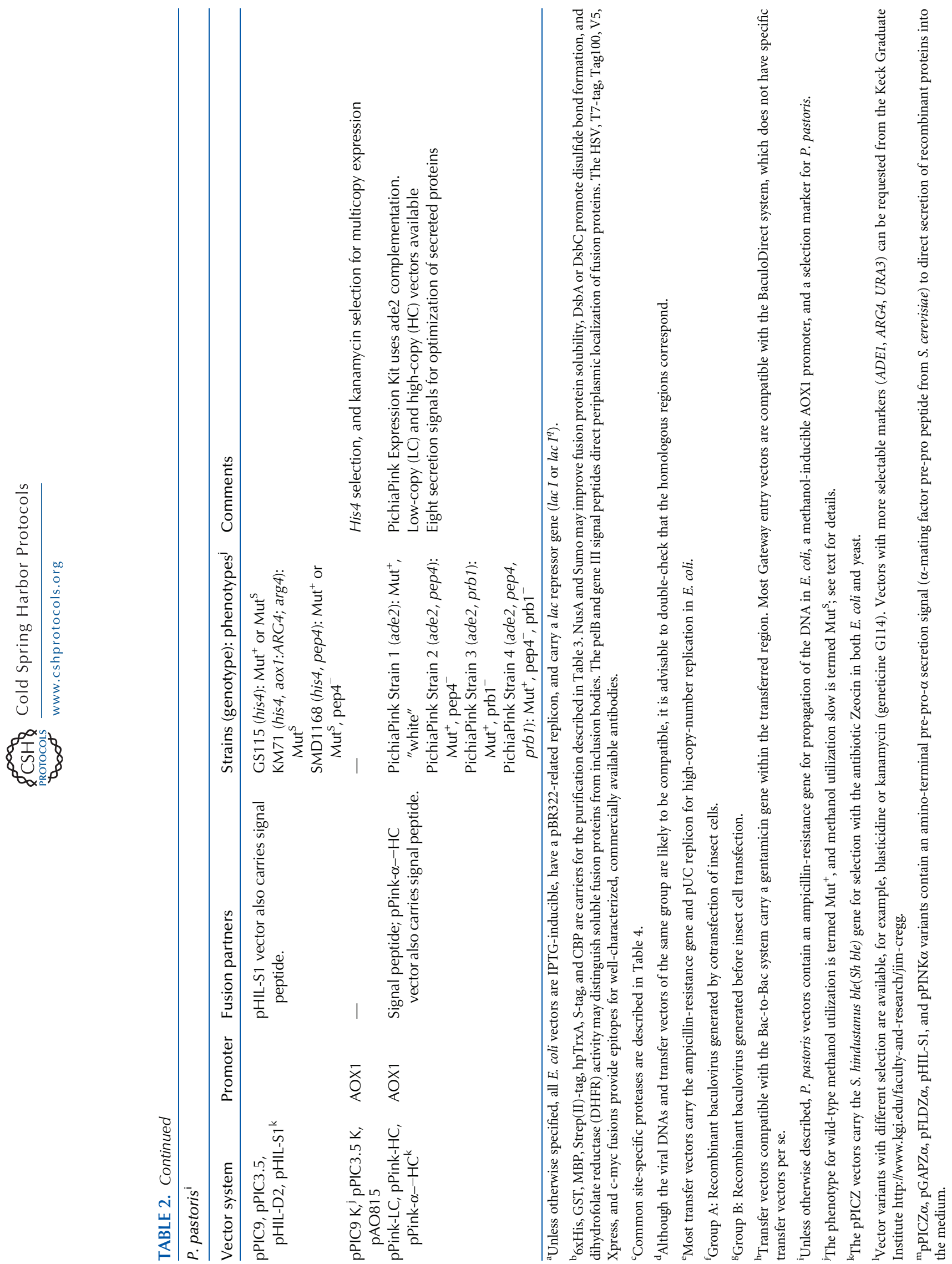
Downloaded from http://cshprotocols.cshlp.org/ on April 26, 2023 - Published by

Expressing Cloned Genes for Protein Production
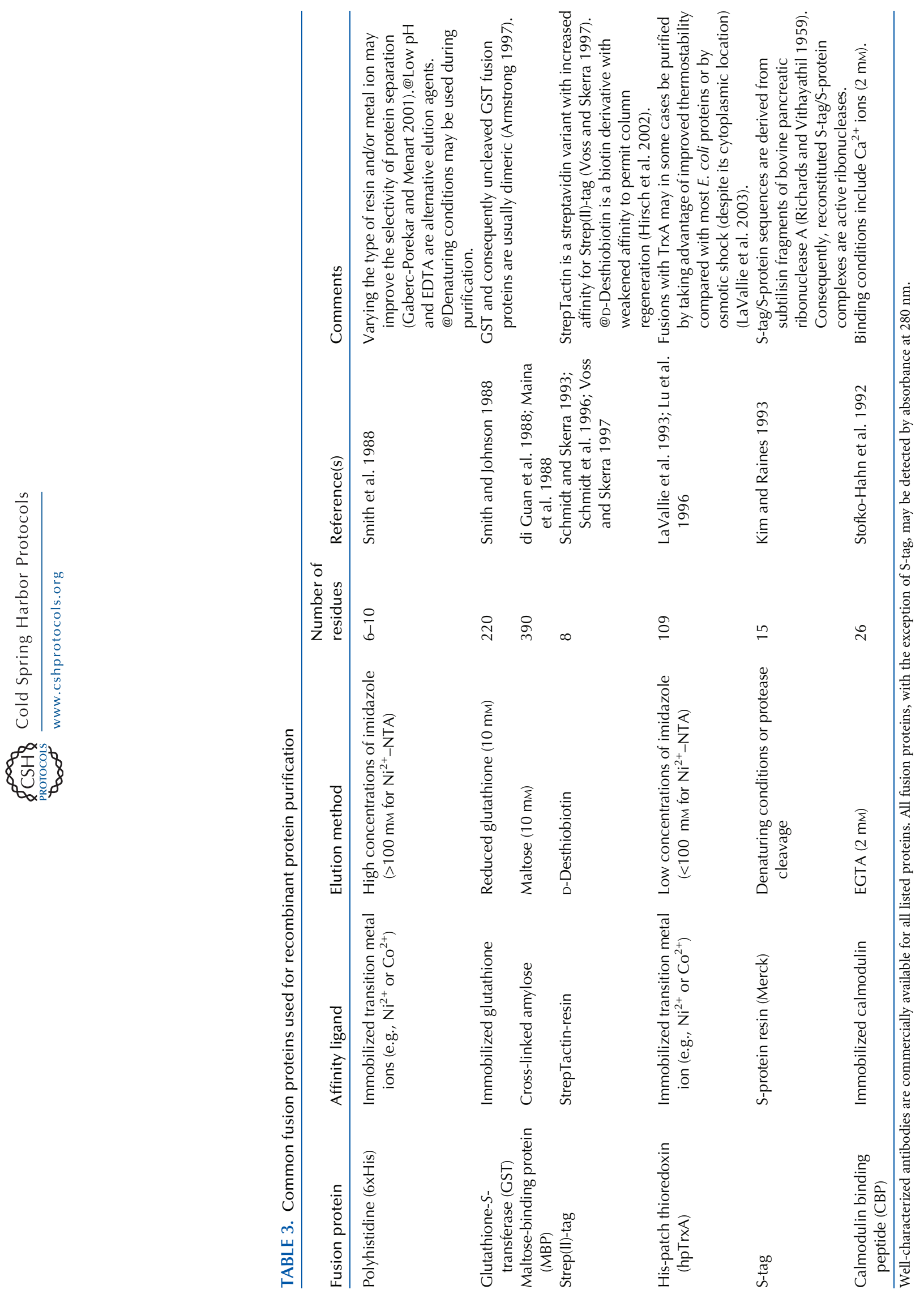


\section{C.L. Kielkopf et al.}

TABLE 4. Common endopeptidases used for cleavage of recombinant fusion proteins

\begin{tabular}{|c|c|c|c|c|}
\hline Protease & Recognition site $^{a}$ & Fusion tag & References & Comments \\
\hline Enterokinase & DDDDK $\downarrow$ & - & $\begin{array}{l}\text { Light et al. 1980; Dykes et al. } \\
\quad 1988\end{array}$ & $\begin{array}{l}\text { Enterokinase, Factor } \mathrm{Xa} \text {, and } \alpha \text {-thrombin are inhibited by } \\
\text { standard serine protease inhibitors such as }\end{array}$ \\
\hline Factor $\mathrm{Xa}^{\mathrm{b}}$ & $\mathrm{I}-(\mathrm{E} / \mathrm{D})-\mathrm{GR} \downarrow$ & - & $\begin{array}{l}\text { Nagai and Thogersen 1984; } \\
\text { Jenny et al. } 2003\end{array}$ & phenylmethanesulfonyl fluoride (PMSF). \\
\hline$\alpha$-Thrombin ${ }^{c}$ & LVPR\GS & - & $\begin{array}{l}\text { Gearing et al. 1989; Jenny } \\
\text { et al. } 2003\end{array}$ & \\
\hline $\mathrm{HRV}-3 \mathrm{C}^{\mathrm{d}}$ & LE-(V/A/T)-LFQ $\downarrow G P$ & GST or His tag & $\begin{array}{l}\text { Cordingley et al. 1990; } \\
\text { Walker et al. } 1994\end{array}$ & Serine protease, only slightly inhibited by PMSF and $\mathrm{Zn}^{2+}$ \\
\hline Genenase $\mathrm{I}^{\mathrm{e}}$ & $\mathrm{HY} \downarrow$ or $\mathrm{H} \downarrow \mathrm{Y}$ & - & $\begin{array}{l}\text { Carter and Wells 1987; } \\
\quad \text { Carter et al. } 1989\end{array}$ & $\begin{array}{l}\text { Engineered subtilisin variant with increased specificity } \\
\text { available from New England Biolabs } \\
\text { Inhibited by standard serine protease inhibitors such as } \\
\text { phenylmethanesulfonyl fluoride (PMSF) }\end{array}$ \\
\hline $\begin{array}{l}\text { Tobacco etch virus } \\
\text { (TEV) protease }\end{array}$ & $\mathrm{ENLYFQ} \downarrow(\mathrm{G} / \mathrm{S})$ & His tag & $\begin{array}{l}\text { Parks et al. 1994; Tropea } \\
\quad \text { et al. } 2009\end{array}$ & $\begin{array}{l}\text { Cysteine protease sensitive to oxidation and inhibited by } \\
\mathrm{Zn}^{2+}(>5 \mathrm{~mm}) \\
\text { Autoproteolysis of wild-type TEV protease is reduced } \\
\text { using a site-directed mutation (Kapust et al. 2001). }\end{array}$ \\
\hline
\end{tabular}

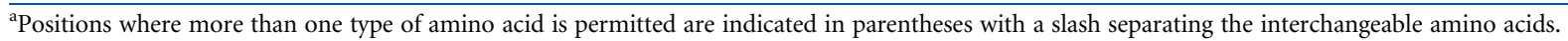

${ }^{\mathrm{b}}$ Enterokinase and Factor Xa will not efficiently cleave a site preceding a proline; Factor Xa also will not cleave a site preceding an arginine.

${ }^{\mathrm{C}}$ Two types of optimum cleavage sites exist for $\alpha$-thrombin: (i) p4-p3-P-(R/K)-p1'-p2', where p3 and p4 are hydrophobic amino acids; and (ii) p2-(R/K)-p1', where p2 or $\mathrm{pl}^{\prime}$ is Gly (Chang 1985).

${ }^{\mathrm{d}}$ PreScission protease is the proprietary name of a GST-tagged HRV-3C protease marketed by GE Healthcare.

${ }^{\mathrm{e}}$ Genenase I has been shown to cleave following other histidines at rates that depend on the structural and sequence context (Carter et al. 1989). Rates of cleavage when the amino acid following the cleavage site (position $\mathrm{pl}^{\prime}$ ) is Asp or Glu are slowest, and no cleavage is observed preceding Pro or Ile.

\section{E. coli Expression Vectors Containing an Inducible Promoter}

E. coli expression vectors typically include an origin of replication, a promoter followed by a cloning site, a transcription termination signal, antibiotic-resistance genes, optional fusion tags, and in some cases, coding sequences for repressor proteins. The replication origins of most $E$. coli expression vectors are based on replicons of the pBR322 family (colicin E1 or the closely related pMB1) and thus belong to the same incompatibility group. Specialized vectors for production of multicomponent complexes (such as the pET Duet system) have been developed to overcome this problem.

Many E. coli expression vectors make use of the lac operon to prevent induction of potentially toxic proteins until an appropriate cell density has been reached (Fig. 2). In general, the lac operator (lac O) is located downstream from the promoter of the target gene, so that binding of the lac repressor blocks transcription initiation until lactose or the isopropyl- $\beta, D-$ thiogalactopyranoside (IPTG) analog is added. A lac repressor gene (lac I) (Farabaugh 1978) or the highly expressed lac Iq allele (Stark 1987; Amann et al. 1988) is constitutively expressed in trans. The strong promoters that drive target protein expression have been developed from either host promoters or bacteriophage sequences. These promoter options are discussed in more detail below. See also Protocol: Expression of Cloned Genes in E. coli Using IPTG-Inducible Promoters (Kielkopf et al. 2021a) and Protocol: Subcellular Localization of Signal Peptide Fusion Proteins Expressed in E. coli (Kielkopf et al. 2021b).

\section{Host Promoters for Foreign Gene Expression in E. coli}

lac Promoter. Any general-purpose vector (pUC, pTZ, pSK, pBluescript, pGEM, etc.) designed for blue/white screening can be used to express a foreign protein, usually as a fusion protein with amino acids encoded by the amino terminus of the lac $Z$ gene and/or the polylinker sequence. Although the lac promoter is not as strong as the tac or trc promoters (see below), the high copy number of most general-purpose vectors allows expression of foreign proteins at respectable levels. Maximum induction of the lac promoter requires the action of the cyclic adenosine monophosphate (cAMP) activator protein (CAP, the crp gene product), which is most active when cells are grown in medium lacking glucose (for review, see Reznikoff 1992). Thus, media with a minimal amount of glucose as a 
A trp-lac (tac) promoter system

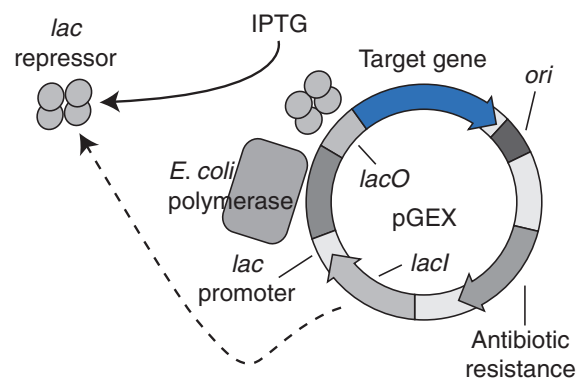

B T7-lac promoter system

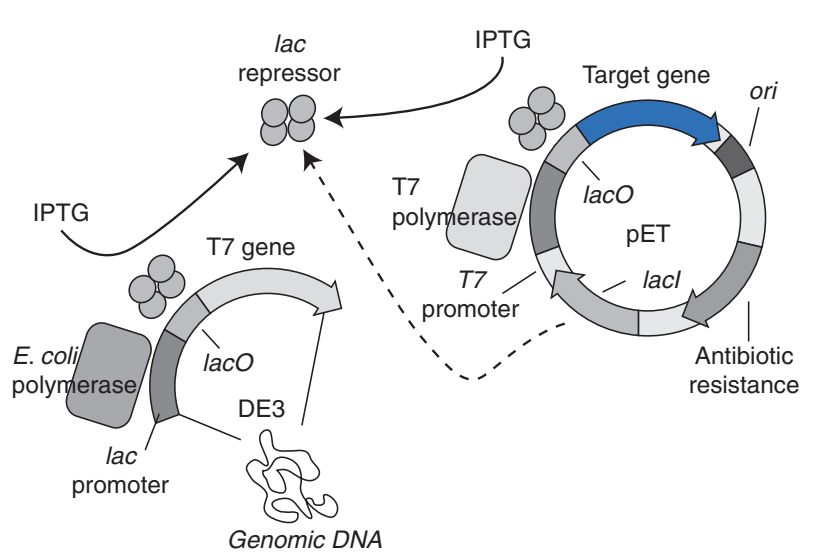

FIGURE 2. Representative vectors for protein expression in Escherichia coli. (A) The tac promoter, found in the pGEX series of vectors, uses the host RNA polymerase. $(B)$ The T7-lac promoter, found in the pET vectors, is transcribed by a T7 RNA polymerase (usually introduced in the host genome) and regulated by a lac operator.

carbon source (such as Luria broth) should be used for expression of genes cloned into vectors with the lac promoter.

trp-lac (tac) Promoter. tac is a hybrid trp-lac promoter containing the -35 region of the trp promoter fused to the -10 region of the lacUV5 promoter; it is regulated by the lac repressor and is independent of cAMP regulation mediated by the crp gene product (Amann et al. 1983; de Boer et al. 1983). A prevalent tac promoter series of GST-fusion plasmids (pGEX) (Smith and Johnson 1988) is available from GE Healthcare (Fig. 2A).

trp-lac (trc) Promoter. trc is another version of the lac repressor-regulated hybrid trp-lac promoter containing the -35 region of the trp promoter fused to the -10 region of the lacUV5 promoter (Amann and Brosius 1985). The only difference between the trc and tac promoters is the distance separating the -35 and -10 regions of the promoter. In the trc promoter, these two elements are separated by a consensus distance (17 bp), whereas in the tac promoter, they are separated by $16 \mathrm{bp}$. This difference has little or no effect on the expression levels of foreign proteins (Amann and Brosius 1985). The expression plasmid pTrcHIS, available from Life Technologies, carries the trc promoter.

The L-Arabinose Operon (araBAD) Promoter. The L-arabinose-inducible bad promoter is an alternative to the lac repressor-regulated vectors for protein production in $E$. coli. The pBAD series of vectors contains an $\operatorname{araC}-P_{B A D}$ fragment from the ara operon (Guzman et al. 1995), which encodes the regulatory AraC protein and a promoter that naturally controls the araBAD genes for arabinose catabolism (for review, see Schleif 2000). The araBAD promoter has valuable characteristics of both stimulating transcription in response to the L-arabinose-bound state of the AraC protein, as well as being repressed by the AraC protein in the absence of cofactor (Englesberg et al. 1969). Media that contain glucose as a carbon source should not be used to express recombinant genes under control of the araBAD promoter (Haggerty and Schleif 1975). 
C.L. Kielkopf et al.

\section{Bacteriophage Promoters for Foreign Gene Expression in E. coli}

T7-lac Promoter. The pET series of vectors, originally developed by Tabor and Richardson (1985) and Studier and Moffatt (1986) and since expanded, allows regulated expression of foreign genes by bacteriophage T7 RNA polymerase (Fig. 2B). Depending on the specific pET vector, the multiple cloning sites allow a coding sequence to be inserted under control of the "natural" promoter for T7 RNA polymerase (the $\phi 10$ promoter) (Studier and Moffatt 1986), or more commonly under the control of the so-called T7-lac promoter, a derivative with the addition of a lac operator (lac O) for stringent regulation (Dubendorff and Studier 1991). For target protein expression, the host strain must contain an inducible copy of the T7 RNA polymerase gene. Usually, this is achieved using a DE3 lysogenic strain bearing the T7 RNA polymerase gene under the control of the lacUV5 promoter. Because this promoter is subject to regulation by CAP as well as the lac repressor, media that contain a minimal amount of glucose as a carbon source (such as LB) should be used to increase target protein expression. However, glucose may be added to decrease leaky T7 RNA polymerase expression during cell growth. Coexpression of low levels of T7 lysozyme, a natural inhibitor of T7 RNA polymerase, serves as a complementary means for reducing basal activity of $\mathrm{T} 7$ promoters for stable gene expression (Studier 1991).

T5-lac Promoter. An alternative type of bacteriophage promoter efficiently competes with host RNAs to recruit the E. coli RNA polymerase and drive production up to $90 \%$ of the total host mRNAs. One common example is the T5 promoter (PN25) (Gentz and Bujard 1985) fused with the E. coli lac operator for transcriptional control (Bujard et al. 1987). The gene encoding the lac repressor is provided either on the vector or separately, for example, by a distinct plasmid such as pREP4 with the $\mathrm{pQE}$ series of vectors from QIAGEN.

\section{Baculovirus Systems for Protein Expression in Insect Cells}

The first continuous insect cell lines were established in the 1960s for the purposes of producing baculovirus as potential insecticides and studying insect cell metabolism (Gao 1958; Gao et al. 1959; Grace 1962). Subsequently in the 1980s, the first baculovirus vector system for expression of heterologous proteins using insect cell cultures was developed independently in the laboratories of Max D. Summers and Lois K. Miller (Fraser et al. 1983; Pennock et al. 1984). In subsequent decades, the popularity of the baculovirus expression system has accelerated because of advances in the methodology and, ultimately, commercial availability. For historical reasons, a limited number of species out of hundreds of known species of baculovirus and Lepidoptera cell lines are used for baculovirus expression systems (for review, see Lynn 2007). Most recombinant baculoviruses are derived from a single multiple nucleopolyhedrovirus, named AcMNPV after the Autographa californica (alfalfa looper) host in which it was originally identified. The common insect cell lines for protein expression include Sf-21 or Sf-9 from S. frugiperda (fall armyworm), Tn-368 or Tn-5 (High-Five) from Trichoplusia ni (cabbage looper), and transgenic variants. The expression levels of distinct recombinant proteins are likely to vary among these cell lines (Wickham et al. 1992; Davis et al. 1993). Below, we compare key differences among recipient viral DNAs and describe the general features of transfer vectors. In-depth descriptions of the baculovirus expression system are given in O'Reilly et al. (1994) and Murhammer (2007).

Three major steps are shared among baculovirus expression systems (Fig. 3A): (1) recombination between the double-stranded DNA virus and a transfer vector that contains the gene of interest, (2) transfection of insect cells to produce large quantities of recombinant baculovirus, and, finally, (3) infection of insect cells to express the desired protein. (See also Protocol: Expression of Cloned Genes Using the Baculovirus Expression System [Kielkopf et al. 2020a].) The large size of the baculovirus genome $(134 \mathrm{~kb})$ prevents the use of traditional ligation techniques to insert the target gene in the viral DNA. Instead, the gene of interest is subcloned into a transfer vector with features for propagation in E. coli. The transfer vector also contains a viral promoter, cloning site, transcription terminator, and selectable marker between two sequences with homology with viral DNA sites (Fig. 3B). This region of the plasmid is then transferred to the baculovirus genome by homologous 
A
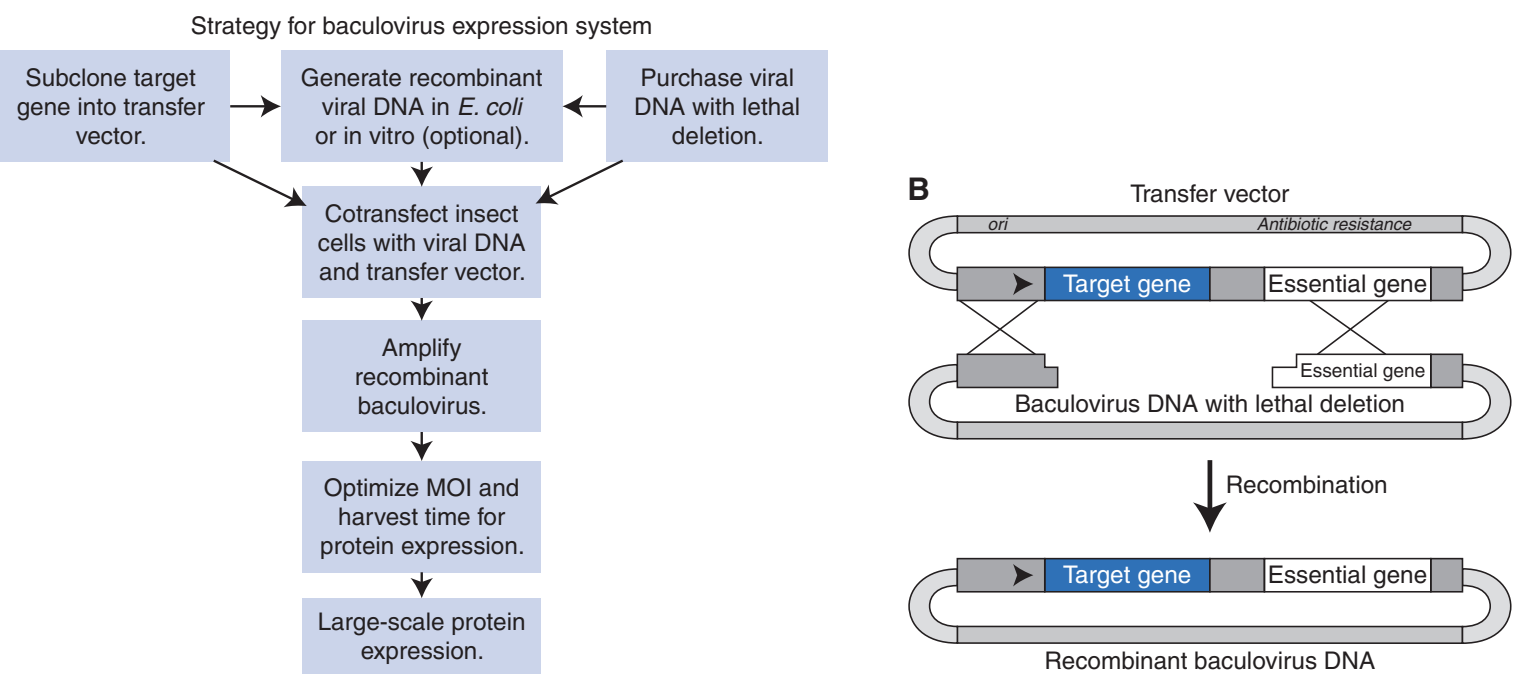

FIGURE 3. The baculovirus expression system. (A) Flow chart of the steps for baculovirus-mediated protein production in insect cells. (MOI) Multiplicity of infection. $(B)$ Schematic diagram of the transfer vector containing the target gene (propagated in E. coli) recombining with the viral DNA.

recombination. In most currently used systems, recombination with the transfer vector replaces the polyhedron locus of the viral DNA (Smith et al. 1983b). Although polyhedron is a coat protein that is not essential for baculovirus replication in insect cell culture, its absence gives rise to a convenient plaque morphology that may be used by an experienced viewer to distinguish recombinant from wildtype baculovirus. The polyhedron region of commercial viral DNAs often is replaced with a lacZ gene for blue/white screening of recombinant virus. A traditional approach for generating recombinant baculovirus depends on homologous recombination within the insect cells following cotransfection of viral DNA and a transfer vector. However, cotransfection of the wild-type viral DNA with a transfer vector results in only $\sim 0.1 \%$ recombinant baculovirus (Smith et al. 1983a). The desired progeny then must be identified by time-consuming techniques such as a viral plaque assay. To solve this problem, several improved strategies have been developed to generate and select the recombinant baculovirus, as summarized below and listed in Table 2 .

\section{Recombinant Baculovirus by Cotransfection of Insect Cells}

Linear Viral DNAs. The fraction of recombinant virus produced by cotransfection may be increased to $\sim 30 \%$ by introducing a unique Bsu36I restriction site and linearizing the viral DNA (Kitts et al. 1990). A second Bsu36I restriction site within an essential gene from the viral genome (ORF1629, a structural protein) further increases the recovery of recombinant baculoviruses to nearly $99 \%$ (Kitts and Possee 1993). Digestion of the two Bsu36I sites removes a portion of ORF1629 from the viral DNA, so that the recircularized baculovirus is no longer viable. Accordingly, the transfer plasmids used with this system must provide a complementary portion of ORF1629 in addition to the gene of interest. A lacZ gene located between the Bsu36I sites of the viral DNA marks nonrecombinant baculovirus with a blue color in the presence of X-Gal. Linear viral DNAs for this traditional method are available from several manufacturers, including BD Biosciences, Merck, Life Technologies, and Clontech.

Viral DNAs as Bacterial Artificial Chromosomes. Although digestion with Bsu36I significantly increases the fraction of recombinant baculovirus, contamination with undigested viral DNA is very difficult to avoid. This problem has been addressed by converting a viral genome that lacks ORF1629 to a low-copy, bacterial artificial chromosome (bacmid) that can be propagated in E. coli (Zhao et al. 2003). Cotransfection of transfer vectors with the bacmid versions of the viral DNAs that lack ORF1629 ensures that $100 \%$ of the recovered baculoviruses have recombined with the transfer 
C.L. Kielkopf et al.

vector. The polyhedro (Oxford Expression Technologies) and BacMagic (Merck) viral DNAs offer this option for recombinant baculovirus production.

\section{Recombinant Baculovirus before Insect Cell Transfection}

Recombination of Linear Viral DNAs In Vitro. The BaculoDirect system from Life Technologies also makes use of viral DNA that has been linearized by several rounds of restriction digestion. However, $a t t R 1$ and $a t t R 2$ sites flanking the polyhedron locus have been engineered surrounding the polyhedron locus to enable in vitro recombination with Gateway entry vectors (Life Technologies). The products of the recombination reaction are then transfected into insect cells for baculovirus production. The viral DNA contains a thymidine kinase gene within the transfer region, so that only recombinant baculoviruses are able to propagate in media containing ganciclovir (Godeau et al. 1992). Because a transfection step is still required, the BaculoDirect procedure requires about the same length of time as cotransfections with viral bacmids, which do not require plaque purification. Furthermore, LR Clonase II mix (Life Technologies) must be purchased for the Gateway reaction. Nevertheless, an advantage of the BaculoDirect system over other strategies for generating recombinant baculovirus is the ability to use a single Gateway entry construct to generate expression constructs for both baculovirus and E. coli expression systems.

Recombination of Viral DNAs in Bacterial Hosts. The Bac-to-Bac Baculovirus Expression System (Life Technologies) is a popular strategy for generating recombinant viral DNA in an E. coli host using techniques that are familiar to most molecular biologists (Luckow et al. 1993). Recombination between a transfer vector and a viral bacmid DNA takes place in a bacterial host (DH10BacTM). The transfer plasmid and bacmid, respectively, contain mini-Tn7 and mini-att $T n 7$ sites that allow a Tn7 transposase provided by a helper plasmid in the DH10BacTM strain to transfer the gene of interest (Barry 1988). The transfer vector carries an antibiotic-resistance gene within the region to be transferred, and recombination disrupts a lacZ $\alpha$ gene of the bacmid DNA. The E. coli colonies containing the recombinant bacmids gain an antibiotic resistance marker and are no longer colored in the presence of X-Gal. The high-molecular-weight DNA recovered from these amplified colonies is used to produce baculovirus by insect cell transfection. An advantage of the Bac-to-Bac System over other systems is the ability to select a single recombinant clone, which also can be sequenced before baculovirus production. All other systems use a mixture of recombinant DNAs for transfection, so that any mutant viruses may be amplified and compete with the viruses expressing the protein of interest.

Several transfer vectors and their salient features are listed in Table 2, with comprehensive information available from the manufacturers' websites. The transfer vectors share some general features with other E. coli vectors, including a selectable ampicillin-resistance gene, a pUC replicon for highcopy-number replication, and a cloning site. Like the vectors for protein expression in E. coli, the transfer vector may also carry coding sequences for protein purification, detection, or secretion inframe with the recombinant gene product. Many of the baculovirus transfer vectors are equipped with $6 \mathrm{xHis}$ tags. Options are also available to monitor protein production. For example, fusions or coexpression with green fluorescent protein (GFP) variants allow the progress of protein expression to be easily monitored by fluorescence of the infected insect cells.

The polyhedron gene promoter is commonly used to drive expression of the foreign protein in insect cells (Smith et al. 1983b). Another option is to use a vector carrying the viral p10 gene (Zuidema et al. 1990). In both cases, a virally encoded RNA polymerase is used to drive transcription at a very late stage of baculovirus infection ( $\sim 1-3$ d postinfection) (Smith et al. $1983 \mathrm{c}$ ), when the polyhedral viral coat normally would be assembled. The levels of expression are high, accounting for up to $50 \%$ of the total insect cell protein. One disadvantage of strong protein expression at a very late stage of infection is that levels of posttranslational modifications decline. A handful of transfer vectors with alternative promoters (e.g., basic protein or gp64) may be preferable for moderate expression of proteins with posttranslational modifications in the late stage of infection $(\sim 8-24 \mathrm{~h}$ postinfection) (Hill-Perkins and Possee 1990; Friesen 1997). Although the recombination sites of almost all commercially available 
transfer vectors flank the polyhedron locus, given the variety of recombination sites, it is advisable to check with the manufacturer before mixing transfer and viral DNAs from different sources.

\section{Vectors for Protein Expression in P. Pastoris}

Most $P$. pastoris vectors rely on the strong, methanol-inducible $A O X 1$ promoter and $A O X 1$ transcription termination sequences to drive expression; the original vectors (Table 2) also contain $3^{\prime} A O X 1$ sequences. Because the $A O X 1$ promoter is tightly repressed by glucose and glycerol, these carbon source cultures can be grown to high density in media containing these compounds before shifting them to methanol-containing medium, which induces rapid, high-level expression (Daly and Hearn 2005). All Pichia vectors are shuttle vectors containing an origin of replication and antibiotic-resistance gene for plasmid maintenance in E. coli, plus an auxotrophic marker based on biosynthetic pathway genes (usually His4) for selection in yeast. For additional information, see Protocol: Expression of Cloned Genes in Pichia pastoris Using the Methanol-Inducible Promoter AOX1 (Kielkopf et al. 2021c).

\section{Examples of Pichia Vectors}

pPIC-Zeocin Vectors. The newer-generation pPIC-Zeocin vectors (pPICZ and pPICZ $\alpha$ variants) (Table 2) combine an expanded multiple cloning site (MSC), a convenient carboxy-terminal myc epitope, and a $6 \mathrm{xHis}$ tag to facilitate detection and purification of the expressed proteins. These vectors also carry a ble gene for selection with the antibiotic Zeocin in both E. coli and yeast. Use of the ble gene has dramatically reduced the vector size $(\sim 3.6 \mathrm{~kb})$ (see Fig. 1 in Protocol: Expression of Cloned Genes in Pichia pastoris Using the Methanol-Inducible Promoter AOX1 [Kielkopf et al. 2021c]), facilitating cloning and downstream mutagenesis of the heterologous gene. The pPICZ $\alpha$ vector also contains the pre-pro- $\alpha$ secretion signal ( $\alpha$-mating factor pre-pro peptide from $S$. cerevisiae) to direct secretion of recombinant proteins into the medium. Promoters available for this vector include (1) pFLDZ, which can be induced by with methanol as well as methylamine, and (2) a constitutive promoter that may be the preferred option for expression using large-scale cultures.

Multicopy Integration Vectors. An advantage of the Zeocin vectors is that higher concentrations of the antibiotic can be used for direct selection of multicopy integrants among Pichia transformants (see Protocol: Expression of Cloned Genes in Pichia pastoris Using the Methanol-Inducible Promoter AOX1 [Kielkopf et al. 2021c]) (Wang et al. 2006; Sunga et al. 2008). In vitro construction of tandem repeats of one or more genes, each containing its own $A O X 1$ promoter and $A O X 1$ transcription termination sequence, is another feature of the pPICZ vector series as well as the multicopy expression vector pAO815. This feature is useful for coexpression of partner proteins at defined stoichiometries (Cregg et al. 2000). However, large plasmids such as pA0815 are difficult to handle. In addition, they should not be linearized with enzymes that cut within the $A O X 1$ promoter because this significantly reduces their transformation efficiency.

PichiaPink Vectors. The PichiaPink Vector Kit offered by Life Technologies takes advantage of $A D E 2$ complementation rather than antibiotic resistance. This ADE2 gene is essential to de novo biosynthesis of purine nucleotides, and its deletion in the parental strains (PichiaPink strains 1-4) (Table 2) causes red-colored colonies because of the accumulation of purine precursors. This facilitates selection because the color of transformant colonies (more or less white) correlates indirectly with the expression level of the protein of interest. Another advantage is that the Life Technologies kit provides vectors equipped with ADE2 promoters of different lengths, which influences the number of plasmid copies that integrate, and is useful for optimizing protein expression. A variety of secretion signal sequences in addition to the pre-pro- $\alpha$-factor are offered for optimizing protein secretion into the medium.

Strains and Phenotypes Generated by Different Vectors. Pichia pastoris strains with a range of genotypes are available (Table 2). Strains X-33, GS115, SMD1168, and PichiaPink contain a functional copy of $A O X 1$, the gene for the alcohol oxidase enzyme responsible for the majority of methanol utilization. These strains have a wild-type methanol utilization phenotype termed $\mathrm{Mut}^{+}$(Daly and 
C.L. Kielkopf et al.

Hearn 2005). Because the strains retain the $\mathrm{Mut}^{+}$phenotype after genomic integration of the vector, they consume methanol rapidly, posing a potential fire hazard during large-scale fermentation. The "methanol utilization slow" or Mut strains such as KM71 contain a nonfunctional AOX1 gene and rely on methanol oxidation by the slower $A O X 2$ enzyme, and thus grow much slower under methanol induction. $\mathrm{Mut}^{\mathrm{S}}$ strains are sometimes better producers of heterologous protein than $\mathrm{Mut}^{+}$strains. If necessary, their growth can be enhanced during induction by a mixed feed of methanol and an alternative carbon source such as sorbitol or mannitol, without repression of AOX1 (Inan and Meagher 2001). The Mut ${ }^{\mathrm{S}}$ phenotype can also arise during transformation of strains GS115 or SMD1168 with the original expression vectors (pPIC9, pPIC3.5, pHIL-D2, pHIL-S1) when a double crossover occurs between the $5^{\prime} A O X 1$ promoter and the $3^{\prime} A O X 1$ sequence during transformation, which leads to replacement of the genomic AOX1 gene (Daly and Hearn 2005).

Strains such as GS115, KM71, and SMD1168 are defective in the histidinol dehydrogenase gene (His4), the auxotrophic selection marker provided by the original expression vectors. The proteasedeficient strain SMD1168 is defective in the vacuolar peptidase A (pep4), a major aspartic protease in Pichia that also activates downstream proteases such as the acid/serine carboxypeptidase $\mathrm{Y}$ and the serine protease B1 ( $p r b 1$ ). Variants SMD1165 and SMD1163, as well as the PichiaPink strains 2, 3, and 4 , are defective in pep4 and/or prb1; these grow more slowly than wild-type strains but may be advantageous if proteolytic degradation of the heterologous protein by the vacuolar pathway (but not the ubiquitin/proteasomal pathway) is a problem.

\section{Pichia Expression Kits}

Pichia expression kits, including vectors and strains, are available through Life Technologies (http:// www.thermofisher.com/us/en/home.html). Limitations of the commercial system include the lack of moderate-strength promoters and the existence of few selectable markers for Pichia transformation (Lin-Cereghino et al. 2008). Interestingly, AOX1 promoter analysis created a library of promoters based on $A O X 1$ deletions/mutations for the fine-tuning of expression in P. pastoris (Hartner et al. 2008). Some vectors and strains with other selection markers (ADE1, ARG4, URA3) are available from James Cregg at the Keck Graduate Institute (http://www.kgi.edu/faculty-and-research/jim-cregg); detailed discussion of the vectors can be found in Lin-Cereghino and Lin-Cereghino (2007).

\section{FUSION PROTEINS}

Recombinant proteins and peptides often are expressed as fusion proteins, composed of carrier sequences linked to the target protein. Two or more open reading frames (ORFs) are joined together in the desired order to encode the fusion protein. Then, expression of the fused reading frames generates the hybrid fusion protein, in which the protein of interest is attached to the amino terminus or the carboxyl terminus of a carrier protein by a standard peptide bond (Itakura et al. 1977; for reviews, see Arnau et al. 2006; Esposito and Chatterjee 2006). Recovery of the target protein is facilitated by including a proteolytic cleavage site at the junction of the fused proteins.

Fusion proteins have a vast array of potential uses.

1. Attaching target proteins to a ligand-binding domain may provide a convenient method to "tag" and purify the target protein sequences.

2. Adding "carrier" sequences may protect the target protein from proteolysis.

3. Adding carrier sequences may improve the solubility of the target protein and may prevent the formation of insoluble inclusion bodies (see Optimization of Expression of Foreign Proteins for more information on dealing with insoluble proteins).

4. Adding well-characterized epitopes may allow the fusion protein to be detected by immunological methods. 
5. Joining the target protein to translocation signals may allow the fusion protein to be directed to specific cellular compartments.

More than 20 different fusion systems have been designed or adapted for affinity purification, with several commonly used purification tags summarized in Table 3. Frequently, the attached target protein is a carrier with high affinity for a specific ligand, which enables almost any fusion protein to be purified by a single step of affinity chromatography. For example, the proteins GST and maltosebinding protein (MBP) are well-known tags for isolation of fusion proteins using chromatographic resins conjugated with their respective ligands, glutathione (Protocol: Purification of Fusion Proteins by Affinity Chromatography on Glutathione Resin [Kielkopf et al. 2020c]) or amylose. Furthermore, GST and MBP, as well as other carriers, often improve fusion protein solubility and accordingly may reduce inclusion body formation in E. coli expression systems (Esposito and Chatterjee 2006). Shorter peptides may be included in the fusion proteins, either as a handle for purification or as a convenient epitope for antibody-based methods. An artificial 6xHis sequence is a prevalent short carrier for

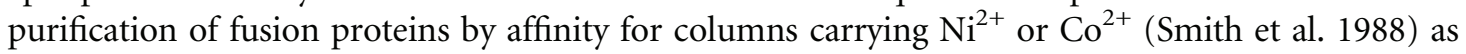
described in Protocol: Purification of Polyhistidine-Tagged Proteins by Immobilized Metal Affinity Chromatography (Kielkopf et al. 2020b). Short epitope tags are often used for antibody-based assays. The Flag tag is a well-known designer octapeptide that is both hydrophilic (to increase fusion protein solubility) and detectable with commercially available monoclonal antibodies (Hopp et al. 1988; for review, see Einhauer and Jungbauer 2001). Several different types of anti-Flag antibodies (called M1, M2, or M5) are marketed either for detection (e.g., using immunoblotting) or as immobilized forms for immunoprecipitation. The five carboxy-terminal amino acids of Flag constitute a recognition site for the protease enterokinase, which serves as a convenient means for removing the carrier peptide from the target protein, as further discussed below (Dykes et al. 1988; Hopp et al. 1988). However, the prohibitive costs of monoclonal antibodies render epitope tags impractical for largescale protein purification.

Another major use of fusion proteins is to add signal peptides for protein translocation. Often, the oxidizing environment and chaperones of the periplasmic space of E. coli or endoplasmic reticulum (ER) of insect and yeast cells assist correct disulfide bond formation and folding. Furthermore, subcellular trafficking through the endoplasmic reticulum and Golgi network is required for $\mathrm{N}$ linked glycosylation of proteins in eukaryotic expression systems. The natural signal peptide often appropriately directs secretion and processing of a recombinant protein expressed in a heterologous host (e.g., mammalian signals in insect cells) (Talmadge et al. 1980; Gray et al. 1985; Jarvis et al. 1993). However, the abilities of individual sequences to facilitate protein translocation and to be appropriately cleaved by the signal peptidase vary widely and may be less efficient in different expression systems (e.g., plant or bacterial signals may be inefficient in insect cells) (Iacono-Connors et al. 1990; Vernet et al. 1990). To avoid problems, a foreign protein's own signal peptide may be required with a well-characterized signal peptide from the expression vector. Popular examples of signal peptides used for recombinant protein localization include those derived from Erwinia carotovora pectate lyase B (pelB) (Keen and Tamaki 1986) or the E. coli outer membrane protein 3a (OmpA) (Ghrayeb et al. 1984) for E. coli hosts, the GP67 baculovirus glycoprotein (Murphy et al. 1993) or honeybee melittin (Tessier et al. 1991) in baculovirus systems, and the S. cerevisiae $\alpha$-mating factor for expression in Pichia (Table 2) (Cregg 2007). Nevertheless, the efficiency of signal peptide translocation and cleavage depends on the amino-terminal structure and sequence of the fused target protein, so that further optimization still may be necessary.

\section{Cleavage of Fusion Proteins}

To obtain the polypeptide of interest in a native and biologically active form, it is often preferable to cleave the tag from the remainder of the fusion protein. Unlike signal peptides, which are normally cleaved by an endogenous signal peptidase following protein translocation, a variety of chemical and enzymatic methods have been developed to cleave the peptide bond between a carrier protein and the protein of interest. In practice, chemical cleavage is of limited utility because most target proteins 
C.L. Kielkopf et al.

contain one or more potential cleavage sites and may be denatured under the harsh reaction conditions. Instead, efficient removal of a tag or carrier protein usually is achieved using site-specific proteases. Accordingly, the polycloning site of most commercially available vectors is located downstream from sequences encoding a carrier protein and a proteolytic cleavage site (Table 2). Several sitespecific proteases commonly used to cleave fusion proteins are summarized in Table 4.

Usually several foreign amino acids remain attached to the amino terminus of the target protein after cleavage. A few proteases, such as enterokinase or Factor Xa, do not require substantial amino acids beyond the carboxyl terminus of the cleavage site. HRV-3C, TEV, and most other specific proteases leave 1-2 amino acids at the carboxyl terminus of the cleavage site, yet often are preferred because of their high sequence specificity and availability in recombinant, tagged form. Moreover, the restriction sites or recombination sites used for cloning into the vector frequently introduce additional amino acids into the target protein. In certain cases, the restriction sites can be carefully chosen to correspond to the sequences recognized by the protease. For example, the BamHI site encodes Gly-Ser and thus can be conveniently positioned at the carboxyl terminus of the thrombin and TEV cleavage sites. In practice, the presence of a few additional amino acids (usually at the amino terminus of the cleaved target protein) does not interfere to a significant extent with protein function. Nevertheless, it remains important to establish that the recombinant protein behaves in a similar manner to the protein composed solely of the native sequence.

In addition to the potential problems associated with introducing extra amino acids at the terminus of the target protein, three other issues are associated with removal of the fusion tag. First, the activity of a particular protease varies for each fusion protein. With many fusion proteins, the efficiency of the proteolytic cleavage reaction may be poor if the protease site is occluded in the context of the folded structure. In these cases, the protease may be induced to cleave once the fusion protein has been partially denatured or after a "spacer" has been inserted at the cost of artificially extending the amino terminus of the target protein. Second, either because the specificity of the protease is not absolute or because the enzyme used for cleavage is contaminated by other proteases, the protein of interest may be cleaved internally at sites that are related to the recognition site (Nagai and Thogersen 1984, 1987; Dykes et al. 1988; Lauritzen et al. 1991). Problems of this type can sometimes be solved by adjusting the digestion conditions (time, temperature, or protease-toprotein ratio). Otherwise, it may be necessary to choose a different protease for cleavage following appropriate adjustments to the expression construct. Third, the cleaved target protein must be isolated from the contaminating carrier protein and the protease. For this purpose, it is often convenient to choose a protease with a fusion tag that matches the carrier on the protein of interest. In this way, both protease and carrier protein can be removed by a single subtractive pass through the affinity resin. The 6xHis- and/or GST-tagged versions of HRV 3C or TEV proteases may be produced in E. coli or purchased from several sources. Although tagged versions of multichain, disulfide-linked proteases such as Factor Xa, thrombin, or enterokinase are more challenging to produce, traditional chromatography or immunological methods can be used to remove these proteases from the protein of interest.

\section{OPTIMIZATION OF EXPRESSION OF FOREIGN PROTEINS}

\section{Optimization of Translation Efficiency: Initiation}

Efficient initiation of translation requires a ribosome-binding site upstream of the initiation codon (Huttenhofer and Noller 1994). For example, during translation initiation in E. coli, the ShineDalgarno sequence, 5-9 nt in length, interacts with the $3^{\prime}$ end of 16S RNA (Shine and Dalgarno 1974; Steitz and Jakes 1975; Steitz 1979). The distance between the Shine-Dalgarno sequence and the initiating ATG codon affects translation efficiency. In vectors in which an ORF is inserted downstream from an initiating ATG, the distance between the Shine-Dalgarno sequence and the initiating codon will already have been optimized. However, if translation of the cloned ORF is initiated at its own 
Codon Usage

ATG, then the initiating codon should be positioned 5-7 nt downstream from the Shine-Dalgarno sequence (Ringquist et al. 1992).

The secondary structure of the translation initiation region also affects the efficiency of gene expression (de Smit and van Duin 1994a,b). In several cases, changing the sequences upstream and downstream from the Shine-Dalgarno sequence to reduce secondary structure has increased gene expression (e.g., see Chen et al. 1994). Similarly, translational coupling, which involves placing the coding region of the gene of interest downstream from a translated sequence, has led to highlevel expression of several genes (e.g., see Makoff and Smallwood 1990; Rangwala et al. 1992). Most commercially available vectors contain appropriately spaced sequences for translation initiation. However, if the $5^{\prime}$ region of the gene of interest is predicted to contain significant secondary structure, it may be possible to increase expression by mutagenesis to decrease this secondary structure, or by fusion with a highly expressed carrier protein.

The genetic code is redundant, using 61 codons to specify 20 amino acids. Only two amino acids (Met and Trp) are specified by a single codon, whereas the remaining 18 are each specified by multiple codons. The synonymous codons that specify a single amino acid are not used with equal frequency (Grantham et al. 1980a,b, 1981).

If the coding region contains a high level or a cluster of rare codons, removal of the rare codons by resynthesis of the gene or by mutagenesis can increase expression (Rangwala et al. 1992). In E. coli, particular problems have been observed when the target sequence contains the rare codons AGA and AGG because they can form fortuitous Shine-Dalgarno sequences within the coding region (Ivanov et al. 1992).

The DNA sequence encoding the amino terminus of the foreign protein can dramatically influence expression levels (Barnes et al. 1991; Bradshaw et al. 1998). For this reason, it is sometimes necessary to use the PCR or site-directed mutagenesis to change the DNA sequences of the first seven or eight codons of the expressed gene to those most frequently used in the particular expression system (Bennetzen and Hall 1982). Wherever possible, the $(\mathrm{G}+\mathrm{C})$ content of the $5^{\prime}$ end of the target gene should be reduced to $<45 \%$ by these procedures.

\section{Optimization of Growth Conditions}

Irrespective of the expression system used, dramatic differences in expression levels are often realized in different media (Weickert et al. 1996). For example, a standard medium such as LB for E. coli can be used to establish the general parameters of expression, but optimum expression is usually achieved only after modification of the growth conditions, which may include using a minimal salts medium such as M9, defined salts medium, or rich media such as Terrific Broth, yeast tryptone (YT), or NZCYM. Similarly, minimal media such as minimal glycerol (MGY) and minimal medium (MM) are useful to establish expression of a heterologous protein in P. pastoris, whereas fine-tuning of $\mathrm{pH}$ (in buffered medium), temperature, and time almost always enhances yield and quality of the protein. For protein expression using baculovirus-infected insect cells, the time and multiplicity of infection are important parameters to optimize. For further information, see the Troubleshooting sections at the ends of the protocols on protein expression (Protocol: Expression of Cloned Genes in E. coli Using IPTG-Inducible Promoters [Kielkopf et al. 2021a], Protocol: Expression of Cloned Genes Using the Baculovirus Expression System [Kielkopf et al. 2020a], and Protocol: Expression of Cloned Genes in Pichia pastoris Using the Methanol-Inducible Promoter AOX1 [Kielkopf et al. 2021c]).

\section{REFERENCES}

Ailor E, Pathmanathan J, Jongbloed JD, Betenbaugh MJ. 1999. A bacterial signal peptidase enhances processing of a recombinant single chain antibody fragment in insect cells. Biochem Biophys Res Commun 255: $444-450$. 
Aller SG, Yu J, Ward A, Weng Y, Chittaboina S, Zhuo R, Harrell PM, Trinh YT, Zhang Q, Urbatsch IL, et al. 2009. Structure of P-glycoprotein reveals a molecular basis for poly-specific drug binding. Science 323: $1718-1722$.

Altmann F, Schwihla H, Staudacher E, Glossl J, Marz L. 1995. Insect cells contain an unusual, membrane-bound $\beta-N$-acetylglucosaminidase probably involved in the processing of protein $\mathrm{N}$-glycans. J Biol Chem 270: 17344-17349.

Amann E, Brosius J. 1985. "ATG vectors" for regulated high-level expression of cloned genes in Escherichia coli. Gene 40: 183-190.

Amann E, Brosius J, Ptashne M. 1983. Vectors bearing a hybrid trp-lac promoter useful for regulated expression of cloned genes in Escherichia coli. Gene 25: 167-178.

Amann E, Ochs B, Abel KJ. 1988. Tightly regulated tac promoter vectors useful for the expression of unfused and fused proteins in Escherichia coli. Gene 69: 301-315.

Andre N, Cherouati N, Prual C, Steffan T, Zeder-Lutz G, Magnin T, Pattus F, Michel H, Wagner R, Reinhart C. 2006. Enhancing functional production of $\mathrm{G}$ protein-coupled receptors in Pichia pastoris to levels required for structural studies via a single expression screen. Protein Sci 15: $1115-1126$.

Armstrong RN. 1997. Structure, catalytic mechanism, and evolution of the glutathione transferases. Chem Res Toxicol 10: 2-18.

Arnau J, Lauritzen C, Petersen GE, Pedersen J. 2006. Current strategies for the use of affinity tags and tag removal for the purification of recombinant proteins. Protein Expr Purif 48: 1-13.

Barnes HJ, Arlotto MP, Waterman MR. 1991. Expression and enzymatic activity of recombinant cytochrome P450 $17 \alpha$-hydroxylase in Escherichia coli. Proc Natl Acad Sci 88: 5597-5601.

Barry GF. 1988. A broad-host-range shuttle system for gene insertion into the chromosomes of Gram-negative bacteria. Gene 71: 75-84.

Bennetzen JL, Hall BD. 1982. Codon selection in yeast. J Biol Chem 257: 3026-3031.

Bradshaw RA, Brickey WW, Walker KW. 1998. N-Terminal processing: The methionine aminopeptidase and $\mathrm{N}^{\alpha}$-acetyl transferase families. Trends Biochem Sci 23: 263-267.

Bujard H, Gentz R, Lanzer M, Stueber D, Mueller M, Ibrahimi I, Haeuptle MT, Dobberstein B. 1987. A T5 promoter-based transcription-translation system for the analysis of proteins in vitro and in vivo. Methods Enzymol 155: 416-433.

Cabrita LD, Bottomley SP. 2004. Protein expression and refolding-A practical guide to getting the most out of inclusion bodies. Biotechnol Annu Rev 10: 31-50.

Carter P, Wells JA. 1987. Engineering enzyme specificity by substrate-assisted catalysis. Science 237: 394-399.

Carter P, Nilsson B, Burnier JP, Burdick D, Wells JA. 1989. Engineering subtilisin $\mathrm{BPN}^{\prime}$ for site-specific proteolysis. Proteins 6: $240-248$.

Cereghino GP, Cregg JM. 1999. Applications of yeast in biotechnology: Protein production and genetic analysis. Curr Opin Biotechnol 10: 422-427.

Chang JY. 1985. Thrombin specificity. Requirement for apolar amino acids adjacent to the thrombin cleavage site of polypeptide substrate. Eur J Biochem 151: 217-224.

Chen H, Bjerknes M, Kumar R, Jay E. 1994. Determination of the optimal aligned spacing between the Shine-Dalgarno sequence and the translation initiation codon of Escherichia coli mRNAs. Nucleic Acids Res 22: 4953-4957.

Cordingley MG, Callahan PL, Sardana VV, Garsky VM, Colonno RJ. 1990. Substrate requirements of human rhinovirus $3 \mathrm{C}$ protease for peptide cleavage in vitro. J Biol Chem 265: 9062-9065.

Cregg JM. 2007. Introduction: Distinctions between Pichia pastoris and other expression systems. Methods Mol Biol 389: 1-10.

Cregg JM, Cereghino JL, Shi J, Higgins DR. 2000. Recombinant protein expression in Pichia pastoris. Mol Biotechnol 16: 23-52.

Daly R, Hearn MT. 2005. Expression of heterologous proteins in Pichia pastoris: A useful experimental tool in protein engineering and production. J Mol Recognit 18: 119-138.

Davis TR, Wickham TJ, McKenna KA, Granados RR, Shuler ML, Wood HA. 1993. Comparative recombinant protein production of eight insect cell lines. In Vitro Cell Dev Biol Anim 29A: 388-390.

de Boer HA, Comstock LJ, Vasser M. 1983. The tac promoter: A functional hybrid derived from the trp and lac promoters. Proc Natl Acad Sci 80: $21-25$ de Smit MH, van Duin J. 1994a. Control of translation by mRNA secondary structure in Escherichia coli. A quantitative analysis of literature data. J Mol Biol 244: 144-150.

de Smit MH, van Duin J. 1994b. Translational initiation on structured messengers. Another role for the Shine-Dalgarno interaction. J Mol Biol 235: 173-184.

di Guan C, Li P, Riggs PD, Inouye H. 1988. Vectors that facilitate the expression and purification of foreign peptides in Escherichia coli by fusion to maltose-binding protein. Gene 67: 21-30.

Dubendorff JW, Studier FW. 1991. Controlling basal expression in an inducible T7 expression system by blocking the target T7 promoter with lac repressor. J Mol Biol 219: 45-59.

Dykes CW, Bookless AB, Coomber BA, Noble SA, Humber DC, Hobden AN. 1988. Expression of atrial natriuretic factor as a cleavable fusion protein with chloramphenicol acetyltransferase in Escherichia coli. Eur J Biochem 174: 411-416.

Einhauer A, Jungbauer A. 2001. The FLAG peptide, a versatile fusion tag for the purification of recombinant proteins. J Biochem Biophys Methods 49: 455-465.

Endo Y, Sawasaki T. 2006. Cell-free expression systems for eukaryotic protein production. Curr Opin Biotechnol 17: 373-380.

Englesberg E, Sheppard D, Squires C, Meronk F Jr. 1969. An analysis of "revertants" of a deletion mutant in the $\mathrm{C}$ gene of the l-arabinose gene complex in Escherichia coli B/r: Isolation of initiator constitutive mutants $\left(I^{c}\right)$. J Mol Biol 43: 281-298.

Esposito D, Chatterjee DK. 2006. Enhancement of soluble protein expression through the use of fusion tags. Curr Opin Biotechnol 17: 353-358.

Falzon L, Suzuki M, Inouye M. 2006. Finding one of a kind: Advances in single-protein production. Curr Opin Biotechnol 17: 347-352.

Farabaugh PJ. 1978. Sequence of the lacI gene. Nature 274: 765-769.

Fraser MJ, Smith GE, Summers MD. 1983. Acquisition of host cell DNA sequences by baculoviruses: Relationship between host DNA insertions and FP mutants of Autographa californica and Galleria mellonella nuclear polyhedrosis viruses. J Virol 47: 287-300.

Friesen PD. 1997. Regulation of baculovirus early gene expression. In The baculoviruses (ed. Miller LK), pp. 141-170. Plenum Press, New York.

Gaberc-Porekar V, Menart V. 2001. Perspectives of immobilized-metal affinity chromatography. J Biochem Biophys Methods 49: 335-360.

Gao S-Y. 1958. Culturing all types of silkworm tissues using the monolayer culture. Chin Sci Bull 7: 219-220.

Gao S-Y, Liu NT, Zia TU. 1959. Tissue culture methods for cultivation of virus grasserie. Acta Virol 3: 55-60.

Gearing DP, Nicola NA, Metcalf D, Foote S, Willson TA, Gough NM, Williams RL. 1989. Production of leukemia inhibitory factor in Escherichia coli by a novel procedure and its use in maintaining embryonic stem cells in culture. Nat Biotechnol 7: 1157-1161.

Gentz R, Bujard H. 1985. Promoters recognized by Escherichia coli RNA polymerase selected by function: Highly efficient promoters from bacteriophage T5. J Bacteriol 164: 70-77.

Ghrayeb J, Kimura H, Takahara M, Hsiung H, Masui Y, Inouye M. 1984. Secretion cloning vectors in Escherichia coli. EMBO J 3: 2437-2442.

Gibbs PE, Zouzias DC, Freedberg IM. 1985. Differential post-translational modification of human type I keratins synthesized in a rabbit reticulocyte cell-free system. Biochim Biophys Acta 824: 247-255.

Glocker B, Hoopes RR Jr, Hodges L, Rohrmann GF. 1993. In vitro transcription from baculovirus late gene promoters: Accurate mRNA initiation by nuclear extracts prepared from infected Spodoptera frugiperda cells. J Virol 67: 3771-3776.

Godeau F, Saucier C, Kourilsky P. 1992. Replication inhibition by nucleoside analogues of a recombinant Autographa californica multicapsid nuclear polyhedrosis virus harboring the herpes thymidine kinase gene driven by the IE-1(0) promoter: A new way to select recombinant baculoviruses. Nucleic Acids Res 20: 6239-6246.

Grace TD. 1962. The development of a cytoplasmic polyhedrosis in insect cells grown in vitro. Virology 18: $33-42$.

Grantham R, Gautier C, Gouy M. 1980a. Codon frequencies in 119 individual genes confirm consistent choices of degenerate bases according to genome type. Nucleic Acids Res 8: 1893-1912.

Grantham R, Gautier C, Gouy M, Mercier R, Pave A. 1980b. Codon catalog usage and the genome hypothesis. Nucleic Acids Res 8: r49-r62. 
Grantham R, Gautier C, Gouy M, Jacobzone M, Mercier R. 1981. Codon catalog usage is a genome strategy modulated for gene expressivity. Nucleic Acids Res 9: r43-r74.

Graslund S, Nordlund P, Weigelt J, Hallberg BM, Bray J, Gileadi O, Knapp S, Oppermann U, Arrowsmith C, Hui R et al. 2008. Protein production and purification. Nat Methods 5: 135-146.

Gray GL, Baldridge JS, McKeown KS, Heyneker HL, Chang CN. 1985. Periplasmic production of correctly processed human growth hormone in Escherichia coli: Natural and bacterial signal sequences are interchangeable. Gene 39: 247-254.

Guzman LM, Belin D, Carson MJ, Beckwith J. 1995. Tight regulation, modulation, and high-level expression by vectors containing the arabinose pBAD promoter. J Bacteriol 177: 4121-4130.

Haggerty DM, Schleif RF. 1975. Kinetics of the onset of catabolite repression in Escherichia coli as determined by lac messenger ribonucleic acid initiations and intracellular cyclic adenosine $3^{\prime}, 5^{\prime}$-monophosphate levels. J Bacteriol 123: 946-953.

Hamilton SR, Davidson RC, Sethuraman N, Nett JH, Jiang Y, Rios S, Bobrowicz P, Stadheim TA, Li H, Choi BK et al. 2006. Humanization of yeast to produce complex terminally sialylated glycoproteins. Science 313 : 1441-1443.

Hartner FS, Ruth C, Langenegger D, Johnson SN, Hyka P, Lin-Cereghino GP, Lin-Cereghino J, Kovar K, Cregg JM, Glieder A. 2008. Promoter library designed for fine-tuned gene expression in Pichia pastoris. Nucleic Acids Res 36: e76.

Hillebrecht JR, Chong S. 2008. A comparative study of protein synthesis in in vitro systems: From the prokaryotic reconstituted to the eukaryotic extract-based. BMC Biotechnol 8: 58

Hill-Perkins MS, Possee RD. 1990. A baculovirus expression vector derived from the basic protein promoter of Autographa californica nuclear polyhedrosis virus. J Gen Virol 71: 971-976.

Hino M, Kataoka M, Kajimoto K, Yamamoto T, Kido J, Shinohara Y, Baba Y. 2008. Efficiency of cell-free protein synthesis based on a crude cell extract from Escherichia coli, wheat germ, and rabbit reticulocytes. J Biotechnol 133: 183-189.

Hirsch JD, Eslamizar L, Filanoski BJ, Malekzadeh N, Haugland RP, Beechem JM, Haugland RP. 2002. Easily reversible desthiobiotin binding to streptavidin, avidin, and other biotin-binding proteins: Uses for protein labeling, detection, and isolation. Anal Biochem 308: 343-357.

Hoffmann M, Nemetz C, Madin K, Buchberger B. 2004. Rapid translation system: A novel cell-free way from gene to protein. Biotechnol Annu Rev 10: $1-30$.

Hollister J, Grabenhorst E, Nimtz M, Conradt H, Jarvis DL. 2002. Engineering the protein $N$-glycosylation pathway in insect cells for production of biantennary, complex N-glycans. Biochemistry 41: 15093-15104.

Hopp TP, Gallis B, Prickett KS. 1988. A short polypeptide marker sequence useful for recombinant protein identification and purification. Bio/ Technology 6: 1204-1210.

Hoss A, Moarefi I, Scheidtmann KH, Cisek LJ, Corden JL, Dornreiter I, Arthur AK, Fanning E. 1990. Altered phosphorylation pattern of simian virus $40 \mathrm{~T}$ antigen expressed in insect cells by using a baculovirus vector. J Virol 64: 4799-4807.

Hsu TA, Betenbaugh MJ. 1997. Coexpression of molecular chaperone BiP improves immunoglobulin solubility and IgG secretion from Trichoplusia ni insect cells. Biotechnol Prog 13: 96-104.

Huttenhofer A, Noller HF. 1994. Footprinting mRNA-ribosome complexes with chemical probes. EMBO J 13: 3892-3901.

Iacono-Connors LC, Schmaljohn CS, Dalrymple JM. 1990. Expression of the Bacillus anthracis protective antigen gene by baculovirus and vaccinia virus recombinants. Infect Immun 58: 366-372.

Inan M, Meagher MM. 2001. Non-repressing carbon sources for alcohol oxidase (AOX1) promoter of Pichia pastoris. J Biosci Bioeng 92: 585-589.

Itakura K, Hirose T, Crea R, Riggs AD, Heyneker HL, Bolivar F, Boyer HW. 1977. Expression in Escherichia coli of a chemically synthesized gene for the hormone somatostatin. Science 198: 1056-1063.

Ivanov I, Alexandrova R, Dragulev B, Saraffova A, AbouHaidar MG. 1992. Effect of tandemly repeated AGG triplets on the translation of CATmRNA in E. coli. FEBS Lett 307: 173-176.

Jacobs PP, Geysens S, Vervecken W, Contreras R, Callewaert N. 2009. Engineering complex-type $\mathrm{N}$-glycosylation in Pichia pastoris using GlycoSwitch technology. Nat Protoc 4: 58-70.
Jarvis DL, Summers MD, Garcia A Jr, Bohlmeyer DA. 1993. Influence of different signal peptides and prosequences on expression and secretion of human tissue plasminogen activator in the baculovirus system. J Biol Chem 268: 16754-16762.

Jenny RJ, Mann KG, Lundblad RL. 2003. A critical review of the methods for cleavage of fusion proteins with thrombin and factor Xa. Protein Expr Purif 31: 1-11.

Kapust RB, Tözsér J, Fox JD, Anderson DE, Cherry S, Copeland TD, Waugh DS. 2001. Tobacco etch virus protease: Mechanism of autolysis and rational design of stable mutants with wild-type catalytic proficiency. Protein Eng 14: 993-1000.

Katzen F, Chang G, Kudlicki W. 2005. The past, present and future of cellfree protein synthesis. Trends Biotechnol 23: 150-156.

Keen NT, Tamaki S. 1986. Structure of two pectate lyase genes from Erwinia chrysanthemi EC16 and their high-level expression in Escherichia coli. J Bacteriol 168: 595-606.

Khosravi-Far R, Der CJ. 1995. Prenylation analysis of bacterially expressed and insect cell-expressed Ras and Ras-related proteins. Methods Enzymol 255: 46-60.

Kielkopf CL, Bauer W, Urbatsch IL. 2020a. Expression of cloned genes using the baculovirus expression system. Cold Spring Harb Protoc doi:10.1101/ pdb.prot102152.

Kielkopf CL, Bauer W, Urbatsch IL. 2020b. Purification of polyhistidinetagged proteins by immobilized metal affinity chromatography. Cold Spring Harb Protoc doi:10.1101/pdb.prot102194.

Kielkopf CL, Bauer W, Urbatsch IL. 2020c. Purification of fusion proteins by affinity chromatography on glutathione resin. Cold Spring Harb Protoc doi:10.1101/pdb.prot102202.

Kielkopf CL, Bauer W, Urbatsch IL. 2021a. Expression of cloned genes in E. coli using IPTG-inducible promoters. Cold Spring Harb Protoc doi:10.1101/pdb.prot102137.

Kielkopf CL, Bauer W, Urbatsch IL. 2021b. Subcellular localization of signal peptide fusion proteins expressed in E. coli. Cold Spring Harb Protoc doi:10.1101/pdb.prot102145.

Kielkopf CL, Bauer W, Urbatsch IL. 2021c. Expression of cloned genes in Pichia pastoris using the methanol-inducible promoter AOX1. Cold Spring Harb Protoc doi:10.1101/pdb.prot102160.

Kielkopf CL, Bauer W, Urbatsch IL. 2021d. Preparation of cell extracts for purification of soluble proteins expressed in E. coli. Cold Spring Harb Protoc doi:10.1101/pdb.prot102178.

Kielkopf CL, Bauer W, Urbatsch IL. 2021e. Preparation of cell extracts for purification of proteins expressed in Pichia pastoris. Cold Spring Harb Protoc doi:10.1101/pdb.prot102186.

Kielkopf CL, Bauer W, Urbatsch IL. 2021f. Solubilization of expressed proteins from inclusion bodies. Cold Spring Harb Protoc doi:10.1101/pdb. prot102210.

Kielkopf CL, Bauer W, Urbatsch IL. 2021g. Considerations for membrane protein purification. Cold Spring Harb Protoc doi:10.1101/pdb. top102285.

Kim JS, Raines RT. 1993. Ribonuclease S-peptide as a carrier in fusion proteins. Protein Sci 2: 348-356.

Kitts PA, Possee RD. 1993. A method for producing recombinant baculovirus expression vectors at high frequency. BioTechniques 14: 810-817.

Kitts PA, Ayres MD, Possee RD. 1990. Linearization of baculovirus DNA enhances the recovery of recombinant virus expression vectors. Nucleic Acids Res 18: 5667-5672.

Kluwe L, Maeda K, Miegel A, Fujita-Becker S, Maeda Y, Talbo G, Houthaeve T, Kellner R. 1995. Rabbit skeletal muscle $\alpha \alpha$-tropomyosin expressed in baculovirus-infected insect cells possesses the authentic $\mathrm{N}$-terminus structure and functions. J Muscle Res Cell Motil 16: 103-110.

Kozak M. 1987. At least six nucleotides preceding the AUG initiator codon enhance transplantation in mammalian cells. J Mol Biol 196: 947-950.

Kuroda K, Geyer H, Geyer R, Doerfler W, Klenk HD. 1990. The oligosaccharides of influenza virus hemagglutinin expressed in insect cells by a baculovirus vector. Virology 174: 418-429.

Kuroda K, Veit M, Klenk HD. 1991. Retarded processing of influenza virus hemagglutinin in insect cells. Virology 180: 159-165.

Lauritzen C, Tuchsen E, Hansen PE, Skovgaard O. 1991. BPTI and N-terminal extended analogues generated by factor Xa cleavage and cathep$\sin \mathrm{C}$ trimming of a fusion protein expressed in Escherichia coli. Protein Expr Purif 2: 372-378. 
LaVallie ER, DiBlasio EA, Kovacic S, Grant KL, Schendel PF, McCoy JM. 1993. A thioredoxin gene fusion expression system that circumvents inclusion body formation in the E. coli cytoplasm. Biotechnology (NY) 11: $187-193$

LaVallie ER, DiBlasio-Smith EA, Collins-Racie LA, Lu Z, McCoy JM. 2003. Thioredoxin and related proteins as multifunctional fusion tags for soluble expression in E. coli. Methods Mol Biol 205: 119-140.

Light A, Savithri HS, Liepnieks JJ. 1980. Specificity of bovine enterokinase toward protein substrates. Anal Biochem 106: 199-206.

Lin-Cereghino J, Lin-Cereghino GP. 2007. Vectors and strains for expression. Methods Mol Biol 389: 11-26.

Lin-Cereghino J, Hashimoto MD, Moy A, Castelo J, Orazem CC, Kuo P, Xiong S, Gandhi V, Hatae CT, Chan A et al. 2008. Direct selection of Pichia pastoris expression strains using new G418 resistance vectors. Yeast 25: 293-299.

Lindorfer MA, Sherman NE, Woodfork KA, Fletcher JE, Hunt DF, Garrison JC. 1996. G protein $\gamma$ subunits with altered prenylation sequences are properly modified when expressed in Sf9 cells. J Biol Chem 271: 18582-18587.

Long SB, Campbell EB, Mackinnon R. 2005. Crystal structure of a mammalian voltage-dependent Shaker family $\mathrm{K}^{+}$channel. Science 309: 897-893.

Lowe PN, Page MJ, Bradley S, Rhodes S, Sydenham M, Paterson H, Skinner RH. 1991. Characterization of recombinant human Kirsten-ras (4B) pp21 produced at high levels in Escherichia coli and insect baculovirus expression systems. J Biol Chem 266: 1672-1678.

Lu Z, DiBlasio-Smith EA, Grant KL, Warne NW, LaVallie ER, Collins-Racie LA, Follettie MT, Williamson MJ, McCoy JM. 1996. Histidine patch thioredoxins. Mutant forms of thioredoxin with metal chelating affinity that provide for convenient purifications of thioredoxin fusion proteins. J Biol Chem 271: 5059-5065.

Luckow VA, Lee SC, Barry GF, Olins PO. 1993. Efficient generation of infectious recombinant baculoviruses by site-specific transposon-mediated insertion of foreign genes into a baculovirus genome propagated in Escherichia coli. J Virol 67: 4566-4579.

Lueking A, Horn S, Lehrach H, Cahill DJ. 2003. A dual-expression vector allowing expression in E. coli and P. pastoris, including new modifications. Methods Mol Biol 205: 31-42.

Lynn DE. 2007. Available lepidopteran insect cell lines. Methods Mol Biol 388: $117-138$.

Makoff AJ, Smallwood AE. 1990. The use of two-cistron constructions in improving the expression of a heterologous gene in E. coli. Nucleic Acids Res 18: 1711-1718.

Marston FA. 1986. The purification of eukaryotic polypeptides synthesized in Escherichia coli. Biochem J 240: 1-12.

Maina CV, Riggs PD, Grandea AG III, Slatko BE, Moran LS, Tagliamonte JA, McReynolds LA, Guan CD. 1988. An Escherichia coli vector to express and purify foreign proteins by fusion to and separation from maltosebinding protein. Gene 74: 365-373.

McDowell MJ, Joklik WK, Villa-Komaroff L, Lodish HF. 1972. Translation of reovirus messenger RNAs synthesized in vitro into reovirus polypeptides by several mammalian cell-free extracts. Proc Natl Acad Sci 69: 2649-2653.

Mikami S, Kobayashi T, Masutani M, Yokoyama S, Imataka H. 2008. A human cell-derived in vitro coupled transcription/translation system optimized for production of recombinant proteins. Protein Expr Purif 62: $190-198$

Miyamoto C, Smith GE, Farrell-Towt J, Chizzonite R, Summers MD, Ju G. 1985. Production of human c-myc protein in insect cells infected with a baculovirus expression vector. Mol Cell Biol 5: 2860-2865.

Murhammer DW. 2007. Baculovirus and insect cell expression protocols. Humana Press, Totowa, NJ.

Murphy CI, McIntire JR, Davis DR, Hodgdon H, Seals JR, Young E. 1993. Enhanced expression, secretion, and large-scale purification of recombinant HIV-1 gp120 in insect cell using the baculovirus egt and pp67 signal peptides. Protein Expr Purif 4: 349-357.

Murthy TV, Wu W, Qiu QQ, Shi Z, LaBaer J, Brizuela L. 2004. Bacterial cellfree system for high-throughput protein expression and a comparative analysis of Escherichia coli cell-free and whole cell expression systems. Protein Expr Purif 36: 217-225.

Nagai K, Thogersen HC. 1984. Generation of $\beta$-globin by sequence-specific proteolysis of a hybrid protein produced in Escherichia coli. Nature 309: $810-812$.
Nagai K, Thogersen HC. 1987. Synthesis and sequence-specific proteolysis of hybrid proteins produced in Escherichia coli. Methods Enzymol 153: 461-481.

Nirenberg MW, Matthaei JH. 1961. The dependence of cell-free protein synthesis in E. coli upon naturally occurring or synthetic polyribonucleotides. Proc Natl Acad Sci 47: 1588-1602.

Oker-Blom C, Pettersson RF, Summers MD. 1989. Baculovirus polyhedron promoter-directed expression of rubella virus envelope glycoproteins, E1 and E2, in Spodoptera frugiperda cells. Virology 172: 82-91.

O'Reilly DR, Miller LK, Luckow VA. 1994. Baculovirus expression vectors. Oxford University Press, New York.

Parcej DN, Eckhardt-Strelau L. 2003. Structural polyhedronation of neuronal voltage-sensitive $\mathrm{K}^{+}$channels heterologously expressed in Pichia pastoris. J Mol Biol 333: 103-116.

Parks TD, Leuther KK, Howard ED, Johnston SA, Dougherty WG. 1994. Release of proteins and peptides from fusion proteins using a recombinant plant virus proteinase. Anal Biochem 216: 413-417.

Pelham HR, Jackson RJ. 1976. An efficient mRNA-dependent translation system from reticulocyte lysates. Eur J Biochem 67: 247-256.

Pennock GD, Shoemaker C, Miller LK. 1984. Strong and regulated expression of Escherichia coli $\beta$-galactosidase in insect cells with a baculovirus vector. Mol Cell Biol 4: 399-406.

Rangwala SH, Finn RF, Smith CE, Berberich SA, Salsgiver WJ, Stallings WC, Glover GI, Olins PO. 1992. High-level production of active HIV-1 protease in Escherichia coli. Gene 122: 263-269.

Reznikoff WS. 1992. The lactose operon-controlling elements: A complex paradigm. Mol Microbiol 6: 2419-2422.

Richards FM, Vithayathil PJ. 1959. The preparation of subtilisn-modified ribonuclease and the separation of the peptide and protein components. J Biol Chem 234: 1459-1465.

Ringquist S, Shinedling S, Barrick D, Green L, Binkley J, Stormo GD, Gold L. 1992. Translation initiation in Escherichia coli: Sequences within the ribosome-binding site. Mol Microbiol 6: 1219-1229.

Roberts BE, Paterson BM. 1973. Efficient translation of tobacco mosaic virus RNA and rabbit globin 9S RNA in a cell-free system from commercial wheat germ. Proc Natl Acad Sci 70: 2330-2334.

Rosenberg SJ, Rane MJ, Dean WL, Corpier CL, Hoffman JL, McLeish KR. 1998. Effect of $\gamma$ subunit carboxyl methylation on the interaction of $G$ protein $\alpha$ subunits with $\beta \gamma$ subunits of defined composition. Cell Signal 10: $131-136$.

Saida F. 2007. Overview on the expression of toxic gene products in Escherichia coli. Curr Protoc Protein Sci 5: 5.19.1-5.19.13.

Schleif R. 2000. Regulation of the l-arabinose operon of Escherichia coli. Trends Genet 16: 559-565.

Schmidt TG, Skerra A. 1993. The random peptide library-assisted engineering of a C-terminal affinity peptide, useful for the detection and purification of a functional Ig Fv fragment. Protein Eng 6: 109-122.

Schmidt TG, Koepke J, Frank R, Skerra A. 1996. Molecular interaction between the Strep-tag affinity peptide and its cognate target, streptavidin. J Mol Biol 255: 753-766.

Schuck S, Prinz WA, Thorn KS, Voss C, Walter P. 2009. Membrane expansion alleviates endoplasmic reticulum stress independently of the unfolded protein response. J Cell Biol 187: 525-536.

Shine J, Dalgarno L. 1974. The 3'-terminal sequence of Escherichia coli 16S ribosomal RNA: Complementarity to nonsense triplets and ribosome binding sites. Proc Natl Acad Sci 71: 1342-1346.

Smith DB, Johnson KS. 1988. Single-step purification of polypeptides expressed in Escherichia coli as fusions with glutathione S-transferase. Gene 67: 31-40.

Smith GE, Fraser MJ, Summers MD. 1983a. Molecular engineering of the Autographa californica nuclear polyhedrosis virus genome: Deletion mutations within the polyhedron gene. J Virol 46: 584-593.

Smith GE, Summers MD, Fraser MJ. 1983b. Production of human $\beta$ interferon in insect cells infected with a baculovirus expression vector. Mol Cell Biol 3: 2156-2165.

Smith GE, Vlak JM, Summers MD. 1983c. Physical analysis of Autographa californica nuclear polyhedrosis virus transcripts for polyhedron and 10,000-molecular-weight protein. J Virol 45: 215-225.

Smith GE, Ju G, Ericson BL, Moschera J, Lahm HW, Chizzonite R, Summers MD. 1985. Modification and secretion of human interleukin 2 produced in insect cells by a baculovirus expression vector. Proc Natl Acad Sci 82: 8404-8408. 
Smith MC, Furman TC, Ingolia TD, Pidgeon C. 1988. Chelating peptideimmobilized metal ion affinity chromatography. A new concept in affinity chromatography for recombinant proteins. J Biol Chem 263: 7211-7215.

Spirin AS. 2004. High-throughput cell-free systems for synthesis of functionally active proteins. Trends Biotechnol 22: 538-545.

Stark MJ. 1987. Multicopy expression vectors carrying the lac repressor gene for regulated high-level expression of genes in Escherichia coli. Gene 51: 255-267.

Steitz JA. 1979. Prokaryotic ribosome binding sites. Methods Enzymol 60: 311-321.

Steitz JA, Jakes K. 1975. How ribosomes select initiator regions in mRNA: Base pair formation between the $3^{\prime}$ terminus of $16 \mathrm{~S}$ rRNA and the mRNA during initiation of protein synthesis in Escherichia coli. Proc Natl Acad Sci 72: 4734-4738.

Stiles B, Wood HA. 1983. A study of the glycoproteins of Autographa californica nuclear polyhedrosis virus (AcNPV). Virology 131: 230-241.

Stofko-Hahn RE, Carr DW, Scott JD. 1992. A single step purification for recombinant proteins. Characterization of a microtubule associated protein (MAP 2) fragment which associates with the type II cAMPdependent protein kinase. FEBS Lett 302: 274-278.

Studier FW. 1991. Use of bacteriophage T7 lysozyme to improve an inducible T7 expression system. J Mol Biol 219: 37-44.

Studier FW, Moffatt BA. 1986. Use of bacteriophage T7 RNA polymerase to direct selective high-level expression of cloned genes. J Mol Biol 189: 113-130.

Stueber D, Ibrahimi I, Cutler D, Dobberstein B, Bujard H. 1984. A novel in vitro transcription-translation system: Accurate and efficient synthesis of single proteins from cloned DNA sequences. $E M B O J$ 3: 3143-3148.

Sullivan ML, Youker RT, Watkins SC, Brodsky JL. 2003. Localization of the $\mathrm{BiP}$ molecular chaperone with respect to endoplasmic reticulum foci containing the cystic fibrosis transmembrane conductance regulator in yeast. J Histochem Cytochem 51: 545-548.

Sunga AJ, Tolstorukov I, Cregg JM. 2008. Posttransformational vector amplification in the yeast Pichia pastoris. FEMS Yeast Res 8: 870-876.

Tabor S, Richardson CC. 1985. A bacteriophage T7 RNA polymerase/promoter system for controlled exclusive expression of specific genes. Proc Natl Acad Sci 82: 1074-1078.

Talmadge K, Kaufman J, Gilbert W. 1980. Bacteria mature preproinsulin to proinsulin. Proc Natl Acad Sci 77: 3988-3992.
Tessier DC, Thomas DY, Khouri HE, Laliberte F, Vernet T. 1991. Enhanced secretion from insect cells of a foreign protein fused to the honeybee melittin signal peptide. Gene 98: 177-183.

Thomsen DR, Post LE, Elhammer AP. 1990. Structure of O-glycosidically linked oligosaccharides synthesized by the insect cell line Sf9. J Cell Biochem 43: 67-79.

Tropea JE, Cherry S, Waugh DS. 2009. Expression and purification of soluble $\mathrm{His}_{6}$-tagged TEV protease. Methods Mol Biol 498: 297-307.

Vernet T, Tessier DC, Richardson C, Laliberte F, Khouri HE, Bell AW, Storer AC, Thomas DY. 1990. Secretion of functional papain precursor from insect cells. Requirement for N-glycosylation of the pro-region. J Biol Chem 265: 16661-16666.

Voss S, Skerra A. 1997. Mutagenesis of a flexible loop in streptavidin leads to higher affinity for the Strep-tag II peptide and improved performance in recombinant protein purification. Protein Eng 10: 975-982.

Walker PA, Leong LE, Ng PW, Tan SH, Waller S, Murphy D, Porter AG. 1994. Efficient and rapid affinity purification of proteins using recombinant fusion proteases. Biotechnology (NY) 12: 601-605.

Wang Z, Stalcup LD, Harvey BJ, Weber J, Chloupkova M, Dumont ME, Dean M, Urbatsch IL. 2006. Purification and ATP hydrolysis of the putative cholesterol transporters ABCG5 and ABCG8. Biochemistry 45: 9929-9939.

Weickert MJ, Doherty DH, Best EA, Olins PO. 1996. Optimization of heterologous protein production in Escherichia coli. Curr Opin Biotechnol 7: 494-499.

Wickham TJ, Davis T, Granados RR, Shuler ML, Wood HA. 1992. Screening of insect cell lines for the production of recombinant proteins and infectious virus in the baculovirus expression system. Biotechnol Prog 8: 391-396.

Yang C, Mayau V, Godeau F, Goud B. 1992. Characterization of the unprocessed and processed forms of rab6 expressed in baculovirus/insect cell systems. Biochem Biophys Res Commun 182: 1499-1505.

Yokoyama S. 2003. Protein expression systems for structural genomics and proteomics. Curr Opin Chem Biol 7: 39-43.

Zhao Y, Chapman DA, Jones IM. 2003. Improving baculovirus recombination. Nucleic Acids Res 31: e66.

Zubay G. 1973. In vitro synthesis of protein in microbial systems. Аnnu Rev Genet 7: 267-287.

Zuidema D, Schouten A, Usmany M, Maule AJ, Belsham GJ, Roosien J, Klinge-Roode EC, van Lent JW, Vlak JM. 1990. Expression of cauliflower mosaic virus gene I in insect cells using a novel polyhedronbased baculovirus expression vector. J Gen Virol 71: 2201-2209. 


\section{Expressing Cloned Genes for Protein Production, Purification, and Analysis}

Clara L. Kielkopf, William Bauer and Ina L. Urbatsch

Cold Spring Harb Protoc; doi: 10.1101/pdb.top102129 originally published online December 3, 2020

\begin{tabular}{|c|c|}
\hline $\begin{array}{r}\text { Email Alerting } \\
\text { Service }\end{array}$ & Receive free email alerts when new articles cite this article - click here. \\
\hline $\begin{array}{l}\text { Subject } \\
\text { Categories }\end{array}$ & $\begin{array}{l}\text { Browse articles on similar topics from Cold Spring Harbor Protocols. } \\
\text { Bacteria ( } 64 \text { articles) } \\
\text { Cell Biology, general (1382 articles) } \\
\text { Expression of Cloned Genes ( } 80 \text { articles) } \\
\text { Molecular Biology, general (1293 articles) } \\
\text { Protein Expression and Interactions ( } 93 \text { articles) } \\
\text { Proteins and Proteomics, general (575 articles) } \\
\text { Vectors (141 articles) } \\
\text { Virus (71 articles) } \\
\text { Yeast ( } 288 \text { articles) }\end{array}$ \\
\hline
\end{tabular}

